\title{
Removal of Lead From Aqueous Solutions Using Three Biosorbents of Aquatic Origin: Evaluating the Relative Roles of Factors Affecting the Biosorption Process
}

\author{
Maryam Rezaei \\ Islamic Azad University \\ Nima Pourang ( $\nabla$ n_pourang@yahoo.com ) \\ Agricultural Research, Education and Extension Organization (AREEO) \\ Ali Mashinchian Moradi \\ Islamic Azad University
}

\section{Research Article}

Keywords: Aquatics-based biosorbents, Lead, Fish scales, Bivalve shells, Influencing factors, Caspian Sea

Posted Date: August 12th, 2021

DOI: https://doi.org/10.21203/rs.3.rs-782274/v1

License: (c) (1) This work is licensed under a Creative Commons Attribution 4.0 International License.

Read Full License 


\section{Abstract}

The biosorptive potentials of three aquatics-based biosorbents, including shells of a bivalve mollusk and scales of two fish species for $\mathrm{Pb}$ removal from aqueous solutions were evaluated, for the first time. A Box-Behnken design with the response surface methodology was used to investigate the effects of the seven important variables (contact time, temperature, initial concentration, dosage, size, salinity and $\mathrm{pH}$ ) on the sorption capacity of the sorbents. Among the seven studied factors, the effects of biosorbent dosage, initial concentration and $\mathrm{pH}$ were significant for all the response variables, while biosorbent size was not significant for any of the responses. The initial concentration was the most influential factor. The presence of $\mathrm{Pb}$ ions on the surfaces of the biosorbents after the adsorption was clearly confirmed by the SEM-EDX and XRF analyses. The maximum sorption capacities of the biosorbents were comparable to the literature and the descending order was as follows: scales of Rutilus kutum and Oncorhynchus mykiss and the shells of Cerastoderma glaucum. The isotherm studies revealed Langmuir model applicability for the $\mathrm{Pb}$ adsorption by $R$. kutum scales and $C$. glaucum shells, while Freundlich model was fitted to the adsorption by 0 . mykiss scales.

\section{Introduction}

Pollution of aquatic ecosystems caused by heavy metals has been one of the major environmental threats over the last several decades and is of high ecological significance. These concerns are arise from their non-biodegradability, high toxicity and huge discharge into the environment (Yousefi et al. 2016). Heavy metals occur naturally in aquatic ecosystems, but with large variations in concentration. They also enter the environment from various man-made sources. These metals are released into the aquatic environments through direct discharges into both freshwater and marine ecosystems or through indirect routes (Risjani and Minier 2014; Ozseker and Eruz 2017). These hazardous pollutants tend to transfer through the food chains and potentially can cause adverse effects on the health of any organisms at any trophic level. Hence, the removal of heavy metal from contaminated waters has become one of the most imminent environmental problems (Zayadi and Othman 2013a; Shahzad et al. 2017).

Lead $(\mathrm{Pb})$ is classified as a non-essential prevalent toxic element and major environmental health problems, which affects multiple body systems including the hematologic, neurologic, gastrointestinal, renal and cardiovascular systems (Bajić et al. 2013; Rizwan et al. 2018). The major sources of lead in aquatic ecosystem are anthropogenic, including municipal wastewater and industrial effluents discharged from different industries manufacturing batteries, pigments, cables, pipes, ceramics, gasoline, tobacco, steel, food packaging glasses and pesticides (Momčilović et al. 2011; Dileepa Chathuranga et al. 2014). Annually, large quantities of heavy metals, including lead (derived from various urban, agricultural and industrial sources), enter the Southern Caspian Sea either directly or through rivers (Tabari et al. 2010; Karrari et al. 2012). 
There are some widely used methods for removal of heavy metals from wastewater, such as membrane filtration, electrolytic recovery, precipitation, ion exchange, adsorption and so on; however, these conventional methods can cause some important problems such as management of generated wastes, production of toxic sludge that require safe disposal and high cost (Zabochnicka-Świątek and Krzywonos 2014; Xu et al. 2019). In the past three decades, there has been a growing interest in developing low cost and environment friendly materials for removal of heavy metals from wastewater and natural environment (Uddin 2017).

Biosorption is an emerging and promising technology for the removal of toxic metals from industrial effluents and natural waters (Costa et al.2011). The biosorption process utilizes the ability of nonliving biomaterials to eliminate heavy metals from wastewater effluents using metabolically mediated or physico-chemical pathway of uptake, and is based on different mechanisms (e.g. absorption, adsorption, surface complexation, ion exchange and precipitation) (Darge and Mane 2013; Dileepa Chathuranga et al. 2014; Fomina and Gadd 2014).

A wide range of biosorbents have been applied to remove heavy metals, including $\mathrm{Pb}$, from aqueous solutions. Among them, according to the relatively limited but promising previous studies, two types of aquatic origin biosorbents have been found to have good potential in this regard, which include fish scales (Prabu et al. 2012; Darge and Mane 2013; Zayadi and Othman 2013a and b; Othman et al. 2015; Mandal et al. 2016; Adeogun et al. 2018; Kwaansa-Ansah et al. 2019) and mollusk shells (Gao 2013; Ambali et al. 2015; Yousefi et al. 2016; Zhao et al. 2016; Shahzad et al. 2017; Al-Saeedi et al. 2019; Xu et al. 2019).

The main objective of this research was to investigate the removal potential of lead (II) from aqueous solutions by using three aquatic origin biosorbents, i.e. scales of two fish species (Rutilus kutum and Oncorhynchus mykiss) and shells of a bivalve mollusk (Cerastoderma glaucum). The influences of some important parameters, i.e. sorbent dosage, sorbent size, contact time, temperature, initial concentration, $\mathrm{pH}$ and salinity) on the sorption capacity of the biosorbents were also evaluated. The three selected biosorbents are environmentally friendly, economically feasible and abundant. $R$. kutum is the most important commercial bony fish in southern part of the Caspian Sea (Pourang et al. 2018). O. mykiss is the leading freshwater farmed species in Iran (Adeli and Baghaei 2013). C. glaucum has a relatively wide distribution along the Iranian coast of the Caspian Sea (Bahrebar et al. 2020).

It is noticeable that, so far, no report is available on the use of the three investigated biomaterials as biosorbents for the removal of heavy metals or other pollutants from contaminated waters.

\section{Materials And Methods}

\section{Sample collection and preparation}

Shells of C. glaucum (about two kg) were collected from the beaches of Miankaleh area (southeastern Caspian Sea). Fifty rainbow trout specimens were obtained from a fish farm located in Mazandaran 
Province. Fifty $R$. kutum specimens were also randomly collected from commercial beach seine catches in the coastal area (Fig.1). The scales of the specimens were taken from above the lateral line. The shells and scales samples were transferred into plastic containers and taken to the laboratory. The scales and shells were washed several times with fresh running water to eliminate any adhering dirt and debris, and then soaked in double distilled water for $24 \mathrm{~h}$, and later rinsed three times with double distilled water. The scales and shell samples dried at sunlight for two days. They were dried thereafter in oven at $60^{\circ} \mathrm{C}$ until a constant weight. The dried shell fragments were then ground using a mortar and pestle and the scales pulverized in a laboratory blender. The biosorbents screened through a set of standard nylon sieves to obtain the desired particle sizes $(0.4,0.7$ and $1.0 \mathrm{~mm})$. The samples were then preserved in clean air-tight polyethylene containers for the further use (Varshini and Das 2015; Zhao et al. 2016; Bulut et al. 2018).

\section{Metal solution preparation}

The $\mathrm{Pb}$ stock solution was prepared by dissolving $1.598 \mathrm{~g}$ of lead (II) nitrate (Merck, Germany) in 100mL of ultrapure water, diluted with deionized water up to $1000 \mathrm{~mL}$. The working solutions $(30,65$ and 100 $\mathrm{mg} / \mathrm{L}$ ) were prepared by diluting the stock solution with double distilled water. The $\mathrm{pH}$ of the solutions was adjusted by the addition of $0.1 \mathrm{M} \mathrm{HCl}$ or $\mathrm{NaOH}$. All chemicals used in the present study were of analytical grade (Dileepa Chathuranga et al. 2014; Xu et al. 2019).

\section{Biosorbents characterization}

The morphology of the biosorbents before and after $\mathrm{Pb}(\mathrm{II})$ ion adsorption as well as the chemical composition were analyzed by Scanning Electron Microscopy (SEM)(SNE-4500M, SEC, South Korea) coupled with Energy Dispersive X-ray analysis (EDX). Before the analyses, the samples were mounted onto aluminum stubs using double-sided carbon tape, gold coated with a sputter coater. The accelerating voltage for SEM imaging was $20 \mathrm{kV}$ (Echlin, 2009). The biosorbents were also analyzed before and after $\mathrm{Pb}$ adsorption for surface functional groups using Fourier Transform Infrared Spectrometer (FTIR) (Agilent Cary 630 FTIR, Agilent Technologies, USA). The analysis was conducted using potassium bromide pellets as a reference material. The samples were examined in the range $650-4000 \mathrm{~cm}^{-1}$ (Bajić et al. 2013; Zhao et al. 2016; Bulut et al. 2018). Moreover, X-Ray Fluorescence (XRF) (PW 1480, Philips, Netherlands) was used to determine the chemical composition of the biosorbents before and after the $\mathrm{Pb}$ adsorption (Zayadi and Othman 2013a; Chojnacka et al. 2018).

\section{Adsorption isotherms}

Biosorption isotherms were evaluated by varying the initial metal ion concentrations from 30 to 170 $\mathrm{mg} / \mathrm{L}$. In the isotherm experiments, with regards to the results concerning effects of the independent variables on the responses, the values of other independent variables (i.e. biosorbent dosage, contact time, temperature, $\mathrm{pH}$ and salinity) remained constant. In order to diagnose the nature of adsorption (homogeneous or heterogeneous) onto the biosorbents, three theoretical isotherm models, namely Langmuir, Freundlich and Temkin were used. 


\section{Experimental design and data analysis}

Box-Behnken experimental design (BBD) combined with response surface method (RSM) was employed to assess and optimize the effects of selected variables on the responses. Each of the independent variables included three levels coded as $-1,0$, and +1 for low, average, and high values, respectively. The experimental ranges of the independent variables were as follows: initial concentration (30-100 ppm), biosorbent dosage (0.1- 0.3 g/L), biosorbent size (0.4-1.0 mm), contact time (2-5 hour), pH (5.5-7), salinity $(0.2-10 \mathrm{ppt})$ and temperature $\left(20-30^{\circ} \mathrm{C}\right)$. A BBD with 7 factors, 3 levels and 62 runs (with 6 replicates at center point) was used for the optimization of the three responses (PbR: concentration of $\mathrm{Pb}$ adsorbed by scales of Rutilus kutum; $\mathrm{PbO}$ : concentration of $\mathrm{Pb}$ adsorbed by scales of Oncorhynchus mykiss and $\mathrm{PbC}$ : concentration of $\mathrm{Pb}$ adsorbed by shells of Cerastoderma glaucum). Design-expert software (version 11) was utilized to analyze the experimental data. The statistical validation was performed by assessment of statistical parameters such as model F-value, lack of fit F-value, coefficient of determination $\left(R^{2}\right)$, adjusted $R$-squared $\left(R^{2}{ }_{A d j}\right)$, predicted $R$-squared $\left(R^{2}{ }_{\text {Pred }}\right)$, predicted residual error sum of squares (PRESS) and adequate precision (AP). Analysis of variance (ANOVA) was applied to evaluate the statistical significance and adequacy of the model (one test for each response variable) (Yet and Rahim 2014; Kumar and Bishnoi 2017). By constructing a normal probability plot of the residuals, the normality assumption of each ANOVA was checked. Subsequently, the response variables were transformed to achieve normality using Box-Cox procedure (natural logarithmic transformation for all the responses) (Sahoo and Mishra 2014; Tebassi et al. 2016).

\section{Biosorption studies and metal analysis}

The biosorption experiments were carried out discontinuously in Erlenmeyer flasks (250mL). The sample size in the Erlenmeyer was $100 \mathrm{~mL}$. The prepared solutions were shaken at $180 \mathrm{rpm}$ using a vibratory shaker. The experiments were done by varying the seven independent variables according to the BoxBehnken experimental design mentioned previously. The desired $\mathrm{pH}$ of the solutions was maintained by adding $1 \mathrm{~mol} / \mathrm{L} \mathrm{HCl}$ or $\mathrm{NaOH}$ at the beginning of the experiment. All the experiments were performed in triplicates and the mean values were presented. After the biosorption process, the biosorbents were separated from the aqueous solution by filtering using Watchman No.1 filter paper. The biosorbents samples were prepared for $\mathrm{Pb}$ concentration analysis in accordance with the MOOPAM Instruction (2010). Atomic absorption spectrophotometer (AAS) (SOLAAR M5, Thermo Electron Corp., Verona, WI, USA) was employed to measure the concentrations of lead in the biosorbents before and after the process. The difference between these two was considered as the concentration of $\mathrm{Pb}$ adsorbed by the biosorbents. The detection limit (calculated on the basis of ten determinations of the blanks as three times the standard deviations of the blank) was $0.05 \mathrm{ppm}$. The analytical accuracy and precision were verified using standard reference materials (SRMs) (oyster tissue: NIST 1566 b; tuna fish flesh: IAEA-436). The recovery rates were in the range of $96.4-102.6 \%$. The precision of the analyses were estimated by calculating the relative standard deviation (RSD/\%) based on replicate analyses $(n=10)$ of the SRMs. The precision was less than three percent RSD for all the determinations. 


\section{Results}

\section{Statistical analysis and models}

As mentioned previously, in order to measure how well the suggested model fits the experimental data, different statistical parameters were evaluated. The resulting models in the present research were tested by ANOVA. Table 1 shows the ANOVA results for all the three responses. According to the results presented in the table, F-ratios of the models were 53.29, 27.90 and 26.57, while their lack-of-fits were $1.46,0.64$ and 4.46 for $\mathrm{PbR}, \mathrm{PbO}$ and $\mathrm{PbC}$, respectively. The low probability value of the models $(\mathrm{p}<$ $0.0001)$ and non-significant $(p>0.05)$ lack of fits indicate that all the three models are highly significant and valid for the present work. The quadratic polynomial models (except for $\mathrm{PbC}$, which was linear) representing the relationship between the response variables and the chosen factors were generated using the values of the experimental data and given below (equations1 to 3):

$\ln (\mathrm{PbR})=7.28-0.7235 \mathrm{~A}+0.1768 \mathrm{C}+0.0611 \mathrm{D}+1.07 \mathrm{E}-0.6499 \mathrm{~F}-0.2312 \mathrm{G}-0.201 \mathrm{AF}-0.4351 \mathrm{DE}-$

$0.1902 F G+0.4525 A^{2}+0.1315 C^{2}+0.2704 E^{2}$

$\ln (\mathrm{PbO})=6.65-0.5914 \mathrm{~A}-0.0048 \mathrm{~B}-0.0659 \mathrm{C}+1.09 \mathrm{E}-0.4972 \mathrm{~F}-0.1490 \mathrm{G}-0.3333 \mathrm{EG}+0.3406 \mathrm{~A}^{2}+$ $0.5451 \mathrm{~B}^{2}+0.4213 \mathrm{C}^{2}+0.2844 \mathrm{E}^{2}$

$\ln (P b C)=6.14+0.1481 A-0.0151 B+0.0168 C-0.1239 D+0.6585 E+0.3731 F-0.6180 G$

Where $\mathrm{A}=$ Sorbent dosage, $\mathrm{B}=$ Sorbent size $\mathrm{C}=$ Contact time, $\mathrm{D}=$ Temperature, $\mathrm{E}=$ Initial concentration, $\mathrm{F}=$ $\mathrm{pH}$ and $\mathrm{G}=$ Salinity

These equations can be used to predict the responses for given levels of individual factors.

Table 2 lists the parameters used to fit the polynomial models.

Table 1. Analysis of variance summary of all responses $\left(Y_{1}\right.$ to $\left.Y_{3}\right)$ for the three fitted polynomial models. 


\begin{tabular}{|lllllll|}
\hline Source & $\mathrm{Y}_{\mathbf{1}}(\mathrm{PbR})$ & \multicolumn{3}{c|}{$\mathrm{Y}_{\mathbf{3}}(\mathrm{PbO})$} & \multicolumn{3}{c|}{$\mathrm{Y}_{\mathbf{3}}(\mathrm{PbC})$} \\
\cline { 2 - 7 } & F-ratio & p-value & F- ratio & p-value & F- ratio & p-value \\
\hline Model & 53.29 & $<0.0001$ & 27.90 & $<0.0001$ & 26.57 & $<0.0001$ \\
\hline A (Biosorbent Dosage) & 138.31 & $<0.0001$ & 49.62 & $<0.0001$ & 6.41 & 0.0172 \\
\hline B (Biosorbent Size) & & & 0.0032 & 0.9550 & 0.0630 & 0.8036 \\
\hline C (Contact Time) & 8.26 & 0.0060 & 0.6169 & 0.4359 & 0.0764 & 0.7843 \\
\hline D (Temperature) & 0.9873 & 0.3253 & & & 5.27 & 0.0294 \\
\hline E (Initial Concentration) & 301.13 & $<0.0001$ & 169.00 & $<0.0001$ & 75.71 & $<0.0001$ \\
\hline F (pH) & 111.61 & $<0.0001$ & 35.07 & $<0.0001$ & 22.80 & $<0.0001$ \\
\hline G (Salinity) & 14.12 & 0.0005 & 3.15 & 0.0820 & 90.12 & $<0.0001$ \\
\hline AF & 3.56 & 0.0652 & & & & \\
\hline DE & 16.67 & 0.0002 & & & & \\
\hline EG & & & 5.25 & 0.0261 & & \\
\hline FG & 3.19 & 0.0805 & & & & \\
\hline A & 32.61 & $<0.0001$ & 9.81 & 0.0029 & & \\
\hline B & & & 25.12 & $<0.0001$ & & \\
\hline C & 1.46 & 0.3462 & 0.64 & 0.6821 & 4.46 & 0.0517 \\
\hline E & 2.76 & 0.1033 & 15.00 & 0.0003 & & \\
\hline Lack of Fit & 11.64 & 0.0013 & 6.84 & 0.0118 & & \\
\hline
\end{tabular}

$\mathrm{PbR}$ : Concentration of $\mathrm{Pb}$ adsorbed by scales of Rutilus kutum; $\mathrm{PbO}$ : Concentration of $\mathrm{Pb}$ adsorbed by scales of Oncorhynchus mykiss; $\mathrm{PbC}$ : Concentration of $\mathrm{Pb}$ adsorbed by shells of Cerastoderma glaucum.

Table 2. SD, Mean, CV, PRESS, AP and $\mathrm{R}^{2}$ for all the response variables. 


\begin{tabular}{|llll|}
\hline & $\mathrm{Y}_{1}(\mathrm{PbR})$ & $\mathrm{Y}_{\mathbf{2}}(\mathrm{PbO})$ & $\mathrm{Y} 3(\mathrm{PbC})$ \\
\hline Mean & 7.61 & 7.26 & 6.18 \\
\hline $\mathrm{SD}$ & 0.30 & 0.41 & 0.21 \\
\hline $\mathrm{CV}(\%)$ & 3.96 & 5.66 & 3.50 \\
\hline PRESS & 7.83 & 13.70 & 1.90 \\
\hline $\mathrm{R}^{2}$ & 0.93 & 0.86 & 0.87 \\
\hline Adjusted R & 0.91 & 0.83 & 0.84 \\
\hline Predicted $\mathrm{R}^{2}$ & 0.87 & 0.80 & 0.81 \\
\hline AP & 31.63 & 20.92 & 22.48 \\
\hline
\end{tabular}

$\mathrm{PbR}$ : Concentration of $\mathrm{Pb}$ adsorbed by scales of Rutilus kutum; $\mathrm{PbO}$ : Concentration of $\mathrm{Pb}$ adsorbed by scales of Oncorhynchus mykiss; PbC: Concentration of $\mathrm{Pb}$ adsorbed by shells of Cerastoderma glaucum.

In order to investigate the relative effects of each of the independent variables on the response variables (strength and direction of the effects), the perturbation plots were used, which are presented in Fig. 2.

In order to evaluate the interaction of factors on the response variables, response surface and contour plots were drawn (Fig. 3). As can be seen, each plot indicates the simultaneous effects of two independent variables within their investigated ranges, on the response, while keeping the other factors constant, generally at central point.

\section{Structural characteristics of the sorbents}

The FTIR spectra were used to determine the frequency changes in the functional groups existing on the surfaces of the biosorbents, before and after the $\mathrm{Pb}$ adsorption. Fig. 4 shows the approximate positions of the absorbance peaks for the corresponding functional groups. Table 3 summarizes the assignments for the corresponding functional groups before and after the adsorption. As shown in the figure and Table, in case of $C$. glaucum shell, there is a shift in the calcite group from 854.814 to $856.134 \mathrm{~cm}^{-1}$, Si-O group from 1082.454 to $1082.789 \mathrm{~cm}^{-1}, \mathrm{CH}_{2}$ and $\mathrm{CH}_{3}$ groups from 1445.946 to $1449.595 \mathrm{~cm}^{-1}$, while the $\mathrm{C}=0$ group shifts from 1785.548 to $1786.826 \mathrm{~cm}^{-1}$. In the case of the other two studied sorbents, some shifts and disappearances of the peaks correspond to different functional groups can also be deduced from Fig. 4 and Table 3 (i.e. alkanes, sulfonates, $\mathrm{C}-\mathrm{O}, \mathrm{C}-\mathrm{N}, \mathrm{CH}_{2}, \mathrm{CH}_{3}, \mathrm{C}-\mathrm{H}$ for $\mathrm{O}$. mykiss scale and alkanes, sulfonates, $\mathrm{C}-\mathrm{O}, \mathrm{C}-\mathrm{N}, \mathrm{CH}_{2}, \mathrm{CH}_{3}, \mathrm{~N}=\mathrm{O}, \mathrm{C}-\mathrm{C}, \mathrm{C}-\mathrm{H}, \mathrm{OH}, \mathrm{NH}_{2}$ for $R$. kutum scale).

The chemical composition (weight percentage) of the three biosorbents, before and after the adsorption, based on the results of XRF analyses, are presented in Table 4. 
Fig. 5 shows the surface morphologies of the three selected biosorbents before and after the biosorption, characterized using SEM. The EDX spectra of $R$. kutum scales, $O$. mykiss scales and $C$. glaucum shells are presented in Fig. 6 . The spectra are depicted for dark and white areas of the biosorbents' surfaces, before and after the adsorption, along with their elemental composition. In each case, the relevant weight percentages are also presented.

Table 3. Wave number of dominant peaks obtained from FTIR transmission spectra of the three biosorbents (O: O. mykiss scales; R: R. kutum scales; C: C. glaucum shells) before (B) and after (A) Pb adsorption. 


\begin{tabular}{|c|c|c|c|}
\hline \multirow[t]{2}{*}{ Biosorbent } & \multicolumn{2}{|c|}{ Wave number $\left(\mathrm{cm}^{-1}\right)$} & \multirow{2}{*}{$\begin{array}{l}\text { Corresponding functiona } \\
\text { groups }\end{array}$} \\
\hline & B & A & \\
\hline \multirow[t]{4}{*}{ C } & 854.814 & 856.134 & $\mathrm{CO}_{3}{ }^{2-}$ \\
\hline & 1082.454 & 1082.789 & Si-O \\
\hline & 1445.946 & 1449.595 & $\mathrm{CH}_{2}, \mathrm{CH}_{3}$ \\
\hline & 1785.548 & 1786.826 & $C=0$ \\
\hline \multicolumn{4}{|l|}{0} \\
\hline & 690.573 & - & Alkanes \\
\hline & 869.763 & - & Sulfonates \\
\hline & 1000.891 & 1012.951 & $\mathrm{C}-\mathrm{O}$ \\
\hline & 1265.504 & 1242.017 & $\mathrm{C}-\mathrm{N}$ \\
\hline & 1420.036 & 1418.561 & $\mathrm{CH}_{2}, \mathrm{CH}_{3}$ \\
\hline & 1647.368 & - & $\mathrm{C}-\mathrm{C}$ \\
\hline & 2919.036 & 2925.253 & $\mathrm{C}-\mathrm{H}$ \\
\hline & 3362.915 & - & $\mathrm{OH}, \mathrm{NH}_{2}$ \\
\hline \multirow[t]{9}{*}{$\mathrm{R}$} & 685.885 & 668.668 & Alkanes \\
\hline & 873.156 & $\begin{array}{l}\text { 701.887, } 724.624,776.459,848.946 \\
880.824\end{array}$ & Sulfonates \\
\hline & 999.177 & 945.645 & $\mathrm{C}-\mathrm{O}$ \\
\hline & 1262.292 & $\begin{array}{l}1041.086,1118.305,1169.983 \\
1218.037\end{array}$ & $\mathrm{C}-\mathrm{N}$ \\
\hline & 1418.948 & 1418.502 & $\mathrm{CH}_{2}, \mathrm{CH}_{3}$ \\
\hline & 1559.329 & 1464.911 & $\mathrm{~N}=0$ \\
\hline & 1653.375 & $1623.775,1653.452$ & $\mathrm{C}-\mathrm{C}$ \\
\hline & 2925.660 & 2919.623 & $\mathrm{C}-\mathrm{H}$ \\
\hline & 3502.807 & 3118.249 & $\mathrm{O}-\mathrm{H}, \mathrm{NH}_{2}$ \\
\hline
\end{tabular}

Table 4. Chemical composition of (\%weight) of the biosorbents (0: O. mykiss scales; R: R. kutum scales; C: C. glaucum shells) before (B) and after (A) Pb adsorption. 


\begin{tabular}{|c|c|c|c|c|c|c|}
\hline \multirow{3}{*}{$\begin{array}{l}\text { Compound/ } \\
\text { Element }\end{array}$} & \multicolumn{6}{|c|}{ Biosorbent } \\
\hline & \multicolumn{2}{|l|}{0} & \multicolumn{2}{|l|}{$\mathbf{R}$} & \multicolumn{2}{|l|}{ C } \\
\hline & B & A & B & A & B & $A$ \\
\hline $\mathrm{Na}_{2} \mathrm{O}$ & 1.421 & 1.193 & ND & ND & 1.266 & 1.162 \\
\hline $\mathrm{MgO}$ & 1.217 & 1.087 & 1.039 & 0.867 & ND & ND \\
\hline $\mathrm{P}_{2} \mathrm{O}_{5}$ & 35.373 & 34.936 & 24.499 & 23.739 & ND & ND \\
\hline $\mathrm{SO}_{3}$ & 3.637 & 3.071 & 9.452 & 7.973 & 0.255 & 0.171 \\
\hline $\mathrm{CaO}$ & 58.107 & 56.048 & 65.010 & 63.932 & 97.635 & 96.913 \\
\hline $\mathrm{Sr}$ & 0.245 & 0.229 & ND & ND & 0.844 & 0.775 \\
\hline $\mathrm{Pb}$ & ND & 3.436 & ND & 3.489 & ND & 0.979 \\
\hline
\end{tabular}

ND: not detectable

\section{Adsorption isotherms}

The values of parameters associated with equilibrium isotherms of $\mathrm{Pb}$ removal onto the three biosorbents are shown in Table 5. Fig. 7 shows the isotherm models that are fitted to our experimental data.

Table 5. Parameters of Langmuir, Freundlich and Temkin isotherm models for the adsorption of lead onto the three selected biosorbents (0: O. mykiss scales; R: R. kutum scales; C: C. glaucum shells). 


\begin{tabular}{|c|c|c|c|}
\hline Biosorbents & $\begin{array}{l}\text { Isotherm } \\
\text { model }\end{array}$ & Parameter & Value \\
\hline \multirow[t]{10}{*}{$\mathrm{R}$} & \multirow[t]{4}{*}{ Langmuir } & $\mathrm{q}_{\max }(\mathrm{mg} / \mathrm{L})$ & 60.61 \\
\hline & & $\mathrm{K}_{\mathrm{L}}(\mathrm{L} / \mathrm{g})$ & 1.019 \\
\hline & & $\mathrm{R}_{\mathrm{L}}$ range & $0.01-0.03$ \\
\hline & & $\mathrm{R}^{2}$ & 0.9934 \\
\hline & \multirow[t]{3}{*}{ Freunlich } & $\mathrm{n}$ & 2.67 \\
\hline & & $\mathrm{K}_{\mathrm{f}}(\mathrm{L} / \mathrm{g})$ & 7.6722 \\
\hline & & $\mathrm{R}^{2}$ & 0.1844 \\
\hline & \multirow[t]{3}{*}{ Temkin } & $A_{T}(L / g)$ & 12.66 \\
\hline & & $\mathrm{B}_{\mathrm{T}}$ & 297.964 \\
\hline & & $\mathrm{R}^{2}$ & 0.5062 \\
\hline \multirow[t]{10}{*}{0} & \multirow[t]{4}{*}{ Langmuir } & $\mathrm{q}_{\max }(\mathrm{mg} / \mathrm{L})$ & -40.82 \\
\hline & & $\mathrm{K}_{\mathrm{L}}(\mathrm{L} / \mathrm{g})$ & -0.09 \\
\hline & & $\mathrm{R}_{\mathrm{L}}$ range & $-0.07--0.62$ \\
\hline & & $\mathrm{R}^{2}$ & 0.3874 \\
\hline & \multirow[t]{3}{*}{ Freunlich } & $n$ & 0.46 \\
\hline & & $\mathrm{K}_{\mathrm{f}}(\mathrm{L} / \mathrm{g})$ & 1.0204 \\
\hline & & $\mathrm{R}^{2}$ & 0.9860 \\
\hline & \multirow[t]{3}{*}{ Temkin } & $A_{T}(L / g)$ & 1.13 \\
\hline & & $\mathrm{B}_{\mathrm{T}}$ & 76.801 \\
\hline & & $\mathrm{R}^{2}$ & 0.8334 \\
\hline \multirow[t]{4}{*}{$\mathrm{C}$} & \multirow[t]{4}{*}{ Langmuir } & $\mathrm{q}_{\max }(\mathrm{mg} / \mathrm{L})$ & 104.17 \\
\hline & & $\mathrm{K}_{\mathrm{L}}(\mathrm{L} / \mathrm{g})$ & 0.152 \\
\hline & & $\mathrm{R}_{\mathrm{L}}$ range & $0.04-0.18$ \\
\hline & & $\mathrm{R}^{2}$ & 0.9845 \\
\hline
\end{tabular}




\begin{tabular}{|c|c|c|}
\hline \multirow[t]{3}{*}{ Freunlich } & $\mathrm{n}$ & 0.68 \\
\hline & $\mathrm{K}_{\mathrm{f}}(\mathrm{L} / \mathrm{g})$ & 2.3396 \\
\hline & $\mathrm{R}^{2}$ & 0.7386 \\
\hline \multirow[t]{3}{*}{ Temkin } & $\mathrm{A}_{\mathrm{T}}(\mathrm{L} / \mathrm{g})$ & 1.13 \\
\hline & $\mathrm{B}_{\mathrm{T}}$ & 95.306 \\
\hline & $\mathrm{R}^{2}$ & 0.9835 \\
\hline
\end{tabular}

\section{Discussion}

\section{Data fitting to the model and ANOVA}

Considering models 1 to 3 , the values coefficients of determination (i.e. $0.93,0.86$ and 0.87 for $\mathrm{PbR}, \mathrm{PbO}$ and $\mathrm{PbC}$, respectively) indicated a good fit between predicted values and the experimental data points. For a good model fit $\mathrm{R}^{2}$, should be more than 0.8 . In general, the closer the $\mathrm{R}^{2}$ value is to 1.00 indicating the better fitting and more suitable model for the prediction of the response variables. In all the responses, differences between predicted $R^{2}$ and adjusted $R^{2}$ were less than 0.2 (Table 2), which indicates reasonable agreement between regression coefficients. According to the Table, the AP ratios for all the responses are considerably greater than 4 , which describe good model discrimination. Normally the ratio greater than 4 is desirable, for the models to be used effectively. In all the responses, in comparison with the other models, the linear model (for $\mathrm{PbC}$ ) showing higher PRESS value (the smaller the PRESS value, the better the model's predictive ability). The low SD and CV values indicate the high precision and reliability of the experiments. According to Table 2, SD values were $0.30,0.41$ and 0.21 , whereas $\mathrm{CV}$ values were 3.96, 5.66 and 3.50 for $\mathrm{PbR}, \mathrm{PbO}$ and $\mathrm{PbC}$, respectively. As a general rule, $\mathrm{CV}$ should not be higher than ten percent. The CV values calculated in this study were much lower than the limit, indicating high precision of the conducted experiments. The low values of CV showed that the variabilities between the predicted and observed values are low and were indicative of high reliability of the experiments (Apul et al. 2012; Abu Amr et al. 2014; Qiu et al. 2014; Kumar and Bishnoi 2017; Mourabet et al. 2017).

Considering the above mentioned points, all the selected models have high $\mathrm{R}^{2}$ value, significant $\mathrm{F}$-value, a non-significant lack-of-fit p-value, desirable AP values and low SD and CV. The results confirm that the responses can be predicted with high reliability. Hence, the models can be applied for predictive purposes.

\section{Effects of factors on the responses}

\section{Effects of main variables}

Significance of the effects 
Table 1 can be used to determine which factors significantly affect each response (Montgomery 2012). According to the table, factors biosorbent dosage, initial concentration and $\mathrm{pH}$ were significant for all the responses $(p<0.05)$, whereas biosorbent size was not significant for any of the responses. The contact time and temperature were significant only for $\mathrm{PbR}$ and $\mathrm{PbC}$, respectively. The salinity was significant for the response variables $\mathrm{PbR}$ and $\mathrm{PbC}$.

\section{Order of the effects}

The relative effects of significant factors on the responses were determined by evaluating the $p$-values and F-ratios (Table 1). The parameter with the lowest p-value and the highest F-ratio shows the greatest impact on the response variables (Zar 2010). As mentioned previously, the relative influences of the parameters on the response variables may also be deduced from the perturbation plots (Fig. 2). In a perturbation plot, when the variable produces a steep slope or curvature, then the response variable is sensitive to that parameter, while a relatively flat line shows insensitivity to change in that particular variable (Anderson and Whitcomb 2016; Myers et al. 2016). Furthermore, the relative effects can also be distinguished by comparing the coefficients of the factors in the regression models. To evaluate the relative effect of the independent variables, the coefficients calculated in the regression equations (1 to 3 ) can be directly compared (Anderson and Whitcomb 2007). Description of the order of effects of the studied factors on each of the three response variables are provided separately below:

$P b R$ : The initial concentration had the highest F-ratio and the lowest $\mathrm{p}$-value (301.13 and $<0.0001$, respectively). Hence, this factor had the greatest effect on $\mathrm{PbR}$, followed by biosorbent dosage, $\mathrm{pH}$, salinity and contact time (Table 1). The similar results can be obtained from Fig. 2-a. The perturbation plot clearly shows that of the five significant independent variables, biosorbent dosage and initial concentration affect the value of $\mathrm{PbR}$ more than the others. With regards to the values of the model coefficients in Equation 1, a similar decreasing order of effects (with the relevant coefficients) was also observed as follows: initial concentration (1.07), biosorbent dosage (0.7235), $\mathrm{pH}(0.6499)$, salinity (0.2312) and contact time (0.1768).

$\mathrm{PbO}$ : According to Table 1, the factor of initial concentration had the highest F-ratio and the lowest $\mathrm{p}$ value (169.00 and $<0.0001$, respectively). Hence, this factor produced the highest effect on the response, followed by biosorbent dosage and pH. Fig. 2-b clearly shows that initial concentration has the main and the major effect on $\mathrm{PbO}$ followed by biosorbent dosage and $\mathrm{pH}$, which have the medium and low effects on the response, respectively. Considering the regression coefficients in Equation 2, among the three significant factors, the highest and lowest effects on $\mathrm{PbO}$ were for initial concentration and $\mathrm{pH}$, respectively.

$\mathrm{PbC}$ : From the perturbation plot (Fig. 2-c), the following sequence of relative effects of the factors on $\mathrm{PbC}$ can be inferred: initial concentration $>$ salinity $>\mathrm{pH}>$ biosorbent dosage $>$ temperature. The steep slopes in opposite directions for initial concentration and salinity are quite clear. The significantly lower slopes for $\mathrm{pH}$, biosorbent dosage and temperature show less sensitivity of $\mathrm{PbC}$ to changes in these factors. 
These results are consistent with those presented in Table 1 and Equation 3. As can be seen, the factors initial concentration and salinity indicated the highest F-ratios and the regression coefficients and the lowest $p$-values.

\section{Positive and negative effects}

The regression equations (Equation 1 to 3 ) as well as the perturbation plots (Fig. 2) were used to investigate whether the effect of each factor on the responses is positive or negative. In the equations, negative and positive signs before each term show antagonistic and synergistic effects on the response, respectively (El-Gendy et al., 2014). The significant negative and positive effects on each response variable are described below:

PbR: As can be seen in Fig. 2-a and Equation 1, the increase in the factors initial concentration and contact time has positive effect on PbR. On the other hand, the increase in biosorbent dosage has negative effect on $\mathrm{PbR}$. It can be noticed from the figure that the factors $\mathrm{pH}$ and salinity have also the same effect, but less strong.

$\mathrm{PbO}$ : It is observed from Fig. 2-b and Equation 2 that the $\mathrm{PbO}$ increases with increasing initial concentration and decreasing biosorbent dosage and $\mathrm{pH}$.

$\mathrm{PbC}$. Fig. 2-c and Equation 3 depict that with increase in salinity and temperature reduction in $\mathrm{PbC}$ was observed (negative effect), while factors initial concentration, $\mathrm{pH}$ and biosorbent dosage have a positive effect on the response variable.

In order to simplify the comparisons, all of the above-mentioned descriptions about the significance of the effects, the relative effects of significant factors, and the positive or negative effects are summarized in the Table 6.

Table 6. Order of the significant effects of factors on the responses. Minus and plus signs indicate negative and positive, respectively.

\begin{tabular}{|lllll|}
\hline Responses & Factors \\
$\mathrm{PbR}$ & $\mathrm{E}^{+}>\mathrm{A}^{-}>\mathrm{F}^{-}>\mathrm{G}^{-}>\mathrm{C}^{+}$ \\
$\mathrm{PbO}$ & $\mathrm{E}^{+}>\mathrm{A}^{-}>\mathrm{F}^{-}$ \\
$\mathrm{PbC}$ & $\mathrm{E}^{+}>\mathrm{G}^{-}>\mathrm{F}^{+}>\mathrm{A}^{+}>\mathrm{D}^{-}$ \\
\hline
\end{tabular}

$\mathrm{PbR}$ : Concentration of $\mathrm{Pb}$ adsorbed by scales of Rutilus kutum; $\mathrm{PbO}$ : Concentration of $\mathrm{Pb}$ adsorbed by scales of Oncorhynchus mykiss; $\mathrm{PbC}$ : Concentration of $\mathrm{Pb}$ adsorbed by shells of Cerastoderma glaucum; A: Biosorbent dosage; C: Contact time; D: Temperature; E: Initial concentration; F: pH; G: Salinity.

\section{Interaction between influencing factors}


The response surface and contour plots (Fig. 3) are very useful to see the interaction effects of the parameters on the response variables. In general, the shape of the contour plot indicates the natures and extents of the interactions between parameters. A circular contour plot shows that the mutual interactions between corresponding variables are insignificant. In contrast, elliptical or distorted plots are evidence of significant interactions ( Li et al. 2008; Montgomery 2012; Hou et al. 2016; Wong et al. 2017). For each response variable, only the significant interactions (based on Table 1) are shown and described separately below. The elliptical contour shapes in the figures confirm that all the mutual interactions are significant.

PbR: Fig. 3-a depicts that with increase in $\mathrm{pH}$ reduction in $\mathrm{PbR}$ was observed, but it was observed that with increment in biosorbent dosage, $\mathrm{PbR}$ was increased. The maximum PbR (7655 ppm) occurred at biosorbent dosage of $0.1 \mathrm{~g} / \mathrm{L}$ and $\mathrm{pH} 5.5$, while the $\mathrm{PbR}(493 \mathrm{ppm})$ was minimal at biosorbent dosage of $0.3 \mathrm{~g} / \mathrm{L}$ and $\mathrm{pH}$ 7. Fig. 3-b shows that with lower $\mathrm{pH}$ and salinity, higher $\mathrm{PbR}$ was observed. The $\mathrm{PbR}$ was maximal (3009 ppm) at salinity of $0.2 \mathrm{ppt}$ and $\mathrm{pH} 5.5$, while the minimum $\mathrm{PbR}(493 \mathrm{ppm}$ ) was observed at salinity of $0.2 \mathrm{ppt}$ and $\mathrm{pH}$ 7. At higher initial concentration and lower temperature, higher $\mathrm{PbR}$ was observed (Fig. 3-c). The maximum PbR (8376 ppm) occurred at initial concentration of $100 \mathrm{ppm}$ and temperature of $20^{\circ} \mathrm{C}$, while the $\mathrm{PbR}(414 \mathrm{ppm})$ was minimum at initial concentration of $30 \mathrm{ppm}$ and temperature of $30^{\circ} \mathrm{C}$.

According to Equation 1, all the three mentioned mutual interactions had negative effects on the PbR.

$\mathrm{PbO}$ : With regards to Fig. 3-d, the maximum $\mathrm{PbO}$ occurred at low salinity and high initial concentration. The $\mathrm{PbO}$ was maximal (5355 ppm) at initial concentration of $100 \mathrm{ppm}$ and salinity of $0.2 \mathrm{ppt}$, while the minimum $\mathrm{PbO}(310 \mathrm{ppm})$ was observed at initial concentration and salinity of $30 \mathrm{ppm}$ and $0.2 \mathrm{ppt}$, respectively.

According to Equation 2, interaction between salinity and initial concentration had negative effects on the $\mathrm{PbO}$.

Possible causes of the effects

With regards to the results presented in Tables 1 and 6 and Fig. 2, the following explanations can be given about the causes of observed significant effects and comparison with similar studies, separately:

\section{Initial concentration}

The initial concentration had a positive significant effect on all the three dependent variables. The similar findings were also reported on lead biosorption by fish scales and bivalve shells (Zayadi and Othman 2013a; Ayodele and Adekola 2016). This could be arisen from the fact that the initial concentration actually plays the role of the driving force required to control the resistance of the mass transfer of metal ions between the aqueous phase and the surface of the sorbents, so higher initial concentrations of metal ions may increase their adsorption. Moreover, with increasing initial $\mathrm{Pb}$ ions concentration, higher interaction between the metal ions and the biosorbents, and consequently enhancing the availability of 
the binding sites on the surface of the biosorbents, could be expected (Mandal et al. 2016; Sun et al. 2016; Bulut et al. 2018).

\section{Biosorbent dosage}

It seems that in the present study, the selected range of the biosorbents dosage for the response variables $\mathrm{PbR}$ and $\mathrm{PbO}$ is higher than the equilibrium levels (i.e. maximum adsorption capacity of the biosorbents with a certain absorbate), while in terms of $\mathrm{PbC}$ the reverse trend could be observed. Therefore, higher uptake at low biosorbent concentrations for $\mathrm{PbR}$ and $\mathrm{PbO}$ could be due to availability of lower number of $\mathrm{Pb}$ ions per unit mass of the biosorbents. It can also be relevant to aggregation of the biosorbents particles at higher concentrations, thereby lead to a decline in the surface area of adsorbent and also an increase in the diffusion path length (Dileepa Chathuranga et al. 2014; Ayodele and Adekola 2016). The trend observed for $\mathrm{PbC}$ is possibly due to the availability of more functional groups (adsorption sites) along with the increase of the biosorbent dosage. Similar findings had been reported by other studies as well (Osu and Odoemelam 2010; Maghri et al. 2012; Al-Saeedi et al. 2019).

pH

Generally, the $\mathrm{pH}$ of a solution is one of the most effective environmental parameters for adsorption of heavy metal ions because it might affect strongly the degree of ionization and adsorption sites on the sorbent surface during the biosorption process (Abbar et al. 2017; Bulut et al. 2018; Al-Saeedi et al., 2019). In the present research, as was largely expectable, $\mathrm{pH}$ was found to be one of the important parameters affecting the adsorption of $\mathrm{Pb}$ by the studied biosorbents (Table 2).

The findings of several similar researches on the influences of a wider range of $\mathrm{pH}$ (3 to 7) on the metal sorption process of various biosorbents show that in most cases, with the gradual increment of $\mathrm{pH}$, the following specific trends can be observed: a) strong positive influences: with an increase in $\mathrm{pH}$, there is an increase in ligands with negative charges which results in increase binding of positively charged ions such as $\mathrm{Pb}^{2+}$ via the mechanism of ion exchange (Jimoh et al. 2012; Zabochnicka-Świątek and Krzywonos 2014; Varshini and Das 2015), b) slight positive influences: at higher pH, the reduction in adsorption is possibly due to the abundance of $\mathrm{OH}^{-}$ions, causing increased hindrance to diffusion of organics contributing to the metal ions. The main reason for the small increment in metal removal may be that the adsorption sites are no more influenced by the pH change (Jimoh et al. 2012; Abbar et al. 2017), c) negative influences: some more increase in $\mathrm{pH}$ usually leads to precipitation of the hydroxide form of the metals ions; therefore true adsorption would not be feasible; thus a decline in the percentage of metal ions removal could be observed (Ayodele and Adekola 2016; Shahzad et al. 2017).

The results of the present study in terms of scales of the two fish species are consistent with those obtained by some other researchers, e.g. El-Sheikh and Sweileh (2008); Bajić et al. (2013) and Zayadi and Othman (2013a) that explained the Pb biosorption capacity of fish scales decreases gradually with increasing $\mathrm{pH}$ value of the solution, in the $\mathrm{pH}$ range approximately similar to our study. The possible reason for this trend is explained above (regarding the negative effect of $\mathrm{pH}$ ). The observed reverse trend 
in terms of $\mathrm{PbC}$ could be attributed to the fact that the interaction between the functional groups of the biosorbent and the heavy metal ions is dependent upon nature of the surface of biosorbent and chemistry of the biosorbate solution, which in turn depends on the $\mathrm{pH}$ of the solution (Harikishore Kumar Reddya et al. 2010; Chiban et al. 2016). For this reason, in the current study, the maximum biosorption for the scales of both fish species ( $\mathrm{PbR}$ and $\mathrm{PbO}$ ) occurred similarly at $\mathrm{pH} 5.5$, while that for the bivalve shells $(\mathrm{PbC})$ was found at $\mathrm{pH} 7$.

\section{Salinity}

$\mathrm{PbR}$ and $\mathrm{PbC}$ were significantly and negatively affected by the salinity, but no significant effect could be observed on $\mathrm{PbO}$. Generally, salinity is an important parameter in the biosorption process because the existence of the electrolyte ions in an aqueous environment will cause changes in adsorbate activities, and sorbent surface charge by electrostatic (Coulomb) force (Zhu et al. 2016). So far, no previous study has been performed on the influence of this parameter on biosorption of metals using mollusk shells and fish scales. However, according to the results of some researches in which other adosorbents have been applied, it can be inferred that the increase in the biosorptive capacity with decreaing salinity is likely because of the fact that at lower sodium-to-lead ratios, the less competition for binding sites between sodium and lead ions could be occurred, and vice versa (Green-Ruiz et al. 2008; Park et al. 2014).

\section{Contact time}

$\mathrm{PbR}$ was the only response variable that significantly affected by the contact time. The observed positive effect was also reported by Zayadi and Othman (2013a), who found that an increase in contact time leads to increase in $\mathrm{Pb}$ removal from aqueous environment by fish scales as biosorbent. This implies that initially, the biosorbent contains a higher number of binding sites for the binding of $\mathrm{Pb}$. In the studies that the range of contact time was wider compared to that of current research, after a lapse of some time, depending on the biosorbent and the solution environment, the number of unoccupied sites decreased and gradually became saturated (Ayodele and Adekola 2016; Shahzad et al. 2017; Achieng et al. 2019).

\section{Temperature}

Of the three response variables, only $\mathrm{PbC}$ was significantly affected by temperature. This negative effect has also been observed in some other studies concerning the use of mollusk shells as biosorbents for metals removal from aqueous solutions (e.g. Shahzad et al. 2017; Weerasooriyagedra and Anand Kumar 2018). Since, it is believed that sorption reactions are normally exothermic and, therefore, the decrease in biosorption capacity at higher temperatures likely occurs due to damage to the active binding sites in the biosorbent (Yahaya and Don 2014; Shahzad et al. 2017). It is noticeable that, based on the results of various related studies, the effect of temperature on the biosorption process shows different and contradictory behaviors (El-Naggar et al. 2018). The positive effect of temperature on the process, which has been observed in most similar studies, could be attributed to either higher affinity of sites for heavy metal ions or many more binding sites being available on the relevant particle surface at higher temperatures (Ayodele and Adekola 2016; Xu et al. 2019). 


\section{Characterization of the biosorbents}

\section{FT-IR analysis}

Various functional groups play a significant role in the adsorption processes of metal ions as well as the sorption potential of adsorbents. The number and type of functional groups located on the surface of different sorbents affect the adsorption mechanisms (Sooksawat et al. 2017; Gupta et al. 2020). The functional groups actually provide sites for the effective adsorption of heavy metals on the adsorbent surface, and their adsorption potential can be influenced by a relatively wide range of factors (Muthulakshmi Andal et al. 2016). The results of this study showed that the three investigated biosorbents consist of a variety of functional groups capable of binding heavy metal ions. The complexation of functional groups with $\mathrm{Pb}^{2+}$ changes their chemical environment and thus leads to shifts or disappearance of the peaks in the FTIR spectra. In other words, the peak shifts and disappearances observed after the adsorption can be considered strong evidence for adsorption of $\mathrm{Pb}^{2+}$ on the surface of the biosorbents (Zhu and Li 2015; Usman et al. 2019). The presence of similar functional groups as well as their shifts after $\mathrm{Pb}$ adsorption on the surface of different aquatics-based biosorbents were also reported by some other researchers (Prabu et al. 2012; Bajić et al. 2013; Zayadi and Othman 2013a; Othman et al. 2015; Ayodele and Adekola 2016; Shahzad et al. 2017; Ighalo and Eletta 2020).

\section{XRF analysis}

The XRF results (Table 4) showed that the chemical composition of $O$. mykiss and $R$. kutum scales was dominated by $\mathrm{CaO}$ and $\mathrm{P}_{2} \mathrm{O}_{5}$, whereas the contents of the other elements were rather low. In the case of $C$. glaucum shells, calcium oxide was also the main constituent, but $\mathrm{P}_{2} \mathrm{O}_{5}$ was not detectable. These findings are in concordance with the results reported by several other researchers who analyzed the chemical composition of other aquatics-based sorbents (Maghri et al. 2012; Mustakimah et al. 2012; Zayadi and Othman 2013a; Othman et al. 2015; Ayodele and Adekola 2016; Xu et al. 2019). It was observed that after $\mathrm{Pb}$ adsorption, ion percentage of other elements was decreased. In this case other elements may be involved in ion exchange process with the lead ions.

\section{SEM and EDX analysis}

The micrographs reveal the uneven, heterogeneous and slightly rough surface of the adsorbents (especially in the case of $C$. glaucum shell), which may serve as transport and attachment sites for metal ions (Lam et al. 2016; Mendoza-Castillo et al. 2016). Generally, the differences in adsorption capacity of different types of biosorbents depend on a number of factors, among which the surface morphology, composition and porosity are especially important (Homagai et al. 2010; Parida et al. 2017; Neves et al. 2018). Therefore, the observed differences in the surface microstructures of the three biosorbents (Fig. 5-

a) can be effective in their different adsorption capacities. The observed significant changes in the morphological characteristics of the biosorbents and some precipitation on their surfaces after the adsorption (Fig. 5-b) are evidence of the potential of the biosorbents for adsorption and removal of the 
metal ions from aqueous solutions (Park et al. 2007). The results of several other studies have also shown that the surface morphology of the adsorbents of aquatic origin has changed after the adsorption of some heavy metals (e.g. Villanueva-Espinosa et al. 2001; Prabu et al. 2012; Muthulakshmi Andal et al. 2016; Yousefi et al. 2016; Xu et al. 2019, Dulla et al. 2020, El-Naggar et al. 2021). Generally, the emergence of post-biosorption peaks that characterize $\mathrm{Pb}$ (Fig. 6) indicates the binding of the metal ions to the sorbents surfaces. Hence, with regards to the results of EDX analysis, there are strong and logical reasons for adsorption of $\mathrm{Pb}$ ions on the investigated biosorbents (Bansal et al. 2014). The concentration of the adsorbed elements is directly related to the height of the corresponding EDX peaks (Hayeeye et al. 2018). The SEM analyses showed the existence of two regions, i.e., dark and white areas. The dark region is mainly composed of proteins containing large amounts of carbon, oxygen, and sulfur, whereas the white region is mainly consists of inorganic components, including high amounts of calcium and phosphorus (Villanueva-Espinosa et al. 2001; Zayadi and Othman 2013a). The difference between the two regions can also be deduced from the elemental composition of the adsorbent surface, as shown in the insets of the figures. With regards to Fig. 6 , in the case of $C$. glaucum shells and 0 . mykiss scales, the greater $\mathrm{Pb}$ adsorption was detected in the white region, whereas in the case of $R$. kutum scales the darker area showed the higher adsorption capacity. The visible post-adsorption changes of the weight percentages of calcium, phosphorus, carbon, oxygen and sulfur after the sorption revealed that ion exchange seems to be the most important mechanism affecting the bioabsorption process of metal ions, which can occur through various functional groups located on the biosorbents' surfaces (Kizilkaya et al. 2010; Bilal et al. 2018). Therefore, the different adsorption values observed in the white and dark regions are probably mainly caused by the differences in number and type of the functional groups, microstructure, surface morphology and chemical nature of the sorbents (Ramrakhiani et al. 2016; De Freitas et al. 2019; Jin et al. 2020).

\section{Sorption isotherms}

According to values of regression coefficients $\left(R^{2}\right)$, the Langmuir isotherm showed the best fitted values for $R$. kutum scale $\left(R^{2}=0.9934\right)$ and $C$. glaucum shell $\left(R^{2}=0.9845\right)$ (Table 5 and Fig. 7). Therefore, it can be opined that the two biosorbents may have homogeneous surfaces and monolayer adsorption (Deng and Chen, 2019). The separation factor $\left(R_{L}\right)$ values were between 0 and 1 , indicating a favorable adsorption of $\mathrm{Pb}$ onto the two biosorbents (Badi et al. 2018). While the Frenudlich model was suitable for the equilibrium isotherm of 0 . mykiss scale $\left(R^{2}=0.9860\right)$. Contrary to Langmuir isotherm, the Freundlich isotherm is applicable to heterogeneous surfaces and multilayer adsorption (Djahed et al. 2016).

\section{Comparison with other aquatics-based biosorbents}

The biosorption capacities of the three studied biosorbents in the present study in comparison with those of other biosorbents reported is shown in Table 7. These data show that the sorption capacities of the three biosorbents are comparable to those of other sorbents reported in the literature (within the range of 0.86 and $248.00 \mathrm{mg} / \mathrm{g}$ for fish scales and brown seaweed, respectively). 
In general, It should be noted that direct comparison of sorption capacities of different biosorbents listed in the table is difficult due to: a) the sorbents have been investigated under various preparation and test conditions (including contact time, $\mathrm{pH}$, particle size, metal concentration range, temperature, mixing rate and ....), b) the methods of pre-treatment and preparation of the biosorbents are not similar in different investigations, and c) the techniques for determining maximum adsorption capacity (e.g. BBD-designed experiments, Langmuir Isotherm, Freundlich Isotherm, Pseudo-second order kinetics) have been different in various studies. The first and second points show the factors that may play an important role in increasing the adsorption capacity of sorbents for a given heavy metal (Nadeem et al. 2008a; Fomina and Gadd 2014), and the third point indicates the difference in calculation methods.

With regards to Table 7, a comparison of the three biosorbents studied in the present study shows that the ascending order of the sorption capacity is: the shells of $C$. glaucum, scales of $O$. mykiss and scales of $R$. kutum. Given that the preparation methods and experimental conditions were the same for all three sorbents, these differences in adsorption capacities are probably mostly arose from the differences in surface area, morphology and functional groups (Shrestha et al. 2016; Naik et al. 2017). On the other side, according to Regine et al. (2000) the role of the functional groups in biosorption of a given metal by a certain biosorbent is related to several factors, including accessibility of the reactive sites, the number of the sites in the biosorbent, chemical state of the sites (i.e. availability), and affinity between the sites and the particular metal.

Table 7. The comparison of biosorption capacity for lead with various biosorbents. 


\begin{tabular}{|lll|}
\hline Biosorbent & $\begin{array}{l}\text { Max sorption } \\
\text { capacity } \\
(\mathrm{mg} / \mathrm{g})\end{array}$ & Reference \\
\hline Fish scales (Rutilus kutum) & 24.26 & Present study \\
\hline Fish scales (Oncorhynchus mykiss) & 14.39 & Present study \\
\hline $\begin{array}{l}\text { Bivalve mollusk shell (Cerastoderma } \\
\text { glaucum) }\end{array}$ & 1.29 & Present study \\
\hline Fish scales (Labeo rohita) & 196.80 & Nadeem et al. 2008b \\
\hline Fish scales (Genyonemus lineatus) & 0.86 & Onwordi et al. 2019 \\
\hline Fish scales (Cyprinus carpio) & 62.5 & Bajić et al. 2013 \\
\hline Fish fins (Catla catla) & 3.00 & Gupta et al. 2017 \\
\hline $\begin{array}{l}\text { Bivalve mollusk shell (Anodontoides } \\
\text { ferussacianus) }\end{array}$ & 155.04 & Shahzad et al. 2017 \\
\hline Cockle shell & 24.66 & Ayodele and Adekola 2016 \\
\hline $\begin{array}{l}\text { Freshwater snail shell (Melanoides } \\
\text { tuberculate) }\end{array}$ & 0.59 & Castañeda et al. 2012 \\
\hline Chitin of shrimp (Solenocera melantho) & 7.00 & Forutan et al. 2016 \\
\hline Marine brown algae (Cystoseira stricta) & 64.5 & Iddou et al. 2011 \\
\hline Green seaweed (Ulva lactuca) & 2.25 & Sari and Tuzen 2008 \\
\hline Brown seaweed (Cystoseira baccata) & 124.00 & Lodeiro et al. 2006 \\
\hline Brown seaweed (Laminaria japonica) & 248.00 & Luo et al. 2006 \\
\hline Aquatic plant (Hydrilla verticillata) & 2.14 & Chathuranga et al. 2010 \\
\hline Aquatic plant (Myriophyllum spicatum) & 55.12 & \\
\hline
\end{tabular}

\section{Conclusion}

Among the seven studied parameters in this study, the effects of biosorbent dosage, initial concentration and $\mathrm{pH}$ on the $\mathrm{Pb}$ biosorptive potential of all the three sorbents were significant $(\mathrm{p}<0.05)$, while biosorbent size was not significant for any of the response variables. It was found that the initial concentration was the most influential factor, which had positive effect on adsorption capacity of the three biosorbents. The considerable effects of initial concentration on adsorption efficiency of various biosorbents for heavy metals have also been reported by some other researchers (e.g. Osu and Odoemelam 2010; Zayadi and Othman 2013a; Dileepa Chathuranga et al. 2014; Ayodele and Adekola 2016; Al-Saeedi et al. 2019). 
The SEM and EDX analyses confirmed Pb biosorption as obvious changes in the surface morphologies of the sorbents, and as appearance of characteristic peaks in the EDX spectra. The XRF results were also confirmed the presence of $\mathrm{Pb}$ on the surface of the biosorbents after the adsorption and implied the probable ion exchange between the positively charged ions on the sorbents with $\mathrm{Pb}$ ions. The FTIR results showed that the three investigated biosorbents contained several functional groups that can participate in metal binding. The observed shifts and disappearances of the bands indicated that the functional groups were involved or affected by complexation with $\mathrm{Pb}^{2+}$. With regards to the potential roles of functional groups in heavy metals adsorption process (Xie et al. 2017; Badsha et al. 2021), less diversity of the groups on the surface of $C$. glaucum shells compared to the other two biosorbents probably contributes to the lower adsorption capacity of this adsorbent (Table 7).

Among the isotherm models tested, the Langmuir model was in the best agreement with the experimental data for both $\mathrm{PbR}$ and $\mathrm{PbC}$, whereas the Freundlich model agreed well with the adsorption data of $\mathrm{PbO}$.

Generally, it can be concluded that the investigated biosorbents, especially scales of 0 . mykiss and $R$. kutum can be considered as potential biosorbents for the removal of $\mathrm{Pb}$ from aqueous solutions. The biosorbents are promising alternative to the conventional treatment methods due to their low cost, ecofriendliness and easy availability. However, additional studies are recommended to be conducted in this regard to explore: a) possible roles of various pretreatment methods of the biosorbents in their heavy metal removal efficiency, b) influences of other factors on the adsorption capacity of the sorbents, c) efficiency of the biosorbents in the removal of other heavy metals, d) possibility of reuse the biosorbents, e) feasibility of using the selected biosorbents at an industrial scale, f) possibility of using different biosorbents mixtures for enhancement of heavy metals removal efficiency, and g) maximum adsorption capacity of other aquatics-based sorbents.

\section{Declarations}

\section{Acknowledgements}

The authors would like to express their gratitude to INSF (Iran National Science Foundation) for supporting this research under Project No. 97014196.

Ethical Approval Not applicable.

Consent to Participate Not applicable.

Consent to Publish Not applicable.

Funding This work was supported in part by Iran National Science Foundation under Grant 97014196

Competing Interests The authors declare that they have no competing interest.

Availability of data and materials Not applicable. 


\section{References}

References

1. Abbar, B. et al. Experimental investigation on removal of heavy metals (Cu2+, Pb2+, and $\mathrm{Zn} 2+$ ) from aqueous solution by flax fibres. Process Saf Environ Prot, 109, 639-647 (2017).

2. Abu Amr, S. S., Aziz, H. A. \& Bashir, M. J. K. Application of response surface methodology (RSM) for optimization of semi-aerobic landfill leachate treatment using ozone. Appl Water Sci, 4 (3), 231-239 (2014).

3. Achieng, G. O., Kowenje, C. O., Lalah, J. O. \& Ojwach, S. O. Preparation, characterization of fish scales biochar and their applications in the removal of anionic indigo carmine dye from aqueous solutions. Water Sci Technol, 80 (11), 2218-2223 (2019).

4. Adeli, A. \& Baghaei, F. Production and supply of rainbow trout in Iran and the world. World J Fish Mar Sci, 5 (3), 335-341 (2013).

5. Adeogun, A. I. et al. Biosorption of $\mathrm{Cd} 2+$ and $\mathrm{Zn} 2+$ from aqueous solution using tilapia fish scale (Oreochromis sp): Kinetics, isothermal and thermodynamic study. Desalin Water Treat, 107, 182-194 (2018).

6. Al-Saeedi, J. Y., Akbar, M. M. \& Al-Qarooni, I. H. Removal of Pb (II) and Ni (II) ions from aqueous solution by sea snail shells. J Biodivers Environ Sci, 14 (3), 17-23 (2019).

7. Ambali, A. B., Evbuomwan, B. O. \& Momoh, Y. Comparative study on the adsorption capacity of snail and perewinkle shells for the removal of nickel (II) lon from aqueous solution. Int J Geol Agric Environ Sci, 3 (1), 39-50 (2015).

8. Anderson, M. J. \& Whitcomb, P. J. DOE simplified: Practical tools for effective experimentation 2nd edn241 P(Productivity Press, Boca Raton, 2007).

9. Anderson, M. J., \&Whitcomb, P. J. R. S. M. \& Simplified Optimizing processes using response surface methods for design of experiments. 2nd Edition. Productivity Press. 311 P(2016).

10. Apul, O. G., Wang, Q., Shao, T., Rieck, J. R. \& Karanfil, T. Predictive model development for adsorption of aromatic contaminants by multi-walled carbon nanotubes. Environ Sci Technol, 47, 2295-2303 (2012).

11. Ayodele, D. T. \& Adekola, F. A. Kinetic and thermodynamic studies of the adsorption of lead (II) and zinc (II) Ions onto cockle shell powder.FUW Trends Sci Technol J.1(1),1-10(2016).

12. Badi, M. Y., Azari, A., Pasalari, H., Esrafili, A. \& Farzadkia, M. Modification of activated carbon with magnetic Fe304 nanoparticle composite for removal of ceftriaxone from aquatic solutions. $J$ Mol Liq, 261, 146-154 (2018).

13. Badsha, M. A. H., Khan, M., Wu, B., Kumar, A. \& \&Lo, I. M. C. Role of surface functional groups of hydrogels in metal adsorption: From performance to mechanism. J Hazard Mater, 408, 124463 https://doi.org/10.1016/j.jhazmat.2020.124463 (2021).

14. Bahrebar, S., Negarestan, H., Maghsoudlo, A. \& Danehkar, A. Macrobenthic assemblage structure and distribution at the Boojagh Marine National Park, Southern Caspian Sea, Iran. Iran J Fish Sci, 19 (2), 
$748-767$ (2020).

15. Bajić, Z. J. et al. Equilibrium, kinetic and thermodynamic studies on removal of $\mathrm{Cd}(\mathrm{II}), \mathrm{Pb}(\mathrm{II})$ and As(V) from wastewater using carp (Cyprinus carpio). Dig J Nanomater Bios, 8 (4), 1581-1590 (2013).

16. Bansal, M., Mudhoo, A., Garg, V. K. \& Singh, D. Preparation and characterization of biosorbents and copper sequestration from simulated wastewater. Int J Environ Sci Technol, 11, 1399-1412 (2014).

17. Bilal, M. N. Biosorption: an interplay between marine algae and potentially toxic elements-A. review. Mar Drugs, 16 (2), 1-16 (2018).

18. Bulut, A., Yusan, S., Aytas, S. \& Sert, S. The use of sea shell (Donax trunculus) powder to remove Sr(II) ions from aqueous solutions. Water Sci Technol, 78 (4), 827-836 (2018).

19. Castañeda, M., Mirasol, M. S., Raymundo, L. A. \& Solidum, J. Biosorption and desorption of Pb(II) from simulated waste water using freshwater snail shells, Melanoides tuberculata Muller (family Thiaridae).In 2nd International Conference on Environment and Bioscience, IACSIT Press, Singapore, 44, 54-59(2012).

20. Chiban, M., Carja, G., Lehutu, G. \& Sinan, F. Equilibrium and thermodynamic studies for the removal of $\mathrm{As}(\mathrm{V})$ ions from aqueous solution using dried plants as adsorbents.. Arab J Chem, 9 (2), s988S999 (2016).

21. Chojnacka, K. et al. Using XRF and ICP-OES in biosorption studies. Molecules 23(8) 2076; doi:10.3390/molecules23082076 (2018).

22. Costa, C. H. Adsorption isotherm of uranyl ions by scales of Corvina fish. Int J Nucl Gov Econ Ecol, 3)3( 280-286 (2011).

23. Darge, A. \& Mane, S. J. Treatment of industrial wastewater by using banana peels and fish scales. Int J Sci Res, 4 (7), 600-604 (2013).

24. De Freitas, G. R., Vieira, M. G. A. \& da Silva, M. G. C. Fixed bed biosorption of silver and investigation of functional groups on acidified biosorbent from algae biomass. Environ Sci Pollut Res Int, 26, 36354-36366 (2019).

25. Deng, S. \& Chen, Y. A study by response surface methodology (RSM) on optimization of phosphorus adsorption with nanospherical calcium carbonate derived from waste. Water Sci Technol.79(1),188197(2019).

26. Dileepa Chathuranga, P. K., Dissanayake, D. M. R. E. A., Priyantha, N., Iqbal, S. S. \& Mohamed Iqbal, M. C. Biosorption and desorption of lead (II) by Hydrilla verticillata. Biorem J, 18, 192-203 (2014).

27. Djahed, B., Shahsavani, E., Khalili Naji, F. \& Mahvi, A. H. A novel and inexpensive method for producing activated carbon from waste polyethylene terephthalate bottles and using it to remove methylene blue dye from aqueous solution. Desalin Water Treat, 57 (21), 9871-9880 (2016).

28. Dulla, J. B., Tamana, M. R., Boddu, S., Pulipati, K. \& Srirama, K. Biosorption of copper(II) onto spent biomass of Gelidiella acerosa (brown marine algae): optimization and kinetic studies. Appl Water Sci, 10, 56 https://doi.org/10.1007/s13201-019-1125-3 (2020). 
29. Echlin, P. Handbook of sample preparation for scanning electron microscopy and X-ray microanalysis332(Springer, USA, 2009).

30. El-Gendy, N. S., Nasser, H. N. \& Abu Amr, S. S. Factorial design and response surface optimization for enhancing a biodesulfurization process. Pet Sci Technol, 32( (14),), 16669-11679 (2014). .

31. El-Naggar, N. E. A., Hamouda, R. A., Mousa, I. E., Abdel-Hamid, M. S. \& Rabei, N. H. Biosorption optimization, characterization, immobilization and application of Gelidium amansii biomass for complete Pb2+ removal from aqueous solutions. Sci Rep, 8, 13456 https://doi.org/10.1038/s41598018-31660-7 (2018).

32. El-Naggar, N. E., Hamouda, R. A., Saddiq, A. A. \& Alkinani, M. H. Simultaneous bioremediation of cationic copper ions and anionic methyl orange azo dye by brown marine alga Fucus vesiculosus. Sci Rep, 11, 3555 https://doi.org/10.1038/s41598-021-82827-8 (2021).

33. El-Sheikh, A. H. \& Sweileh, J. A. Sorption of trace metals on fish scales and application for lead and cadmium pre-concentration with flame atomic absorption determination. Jordan J Chem, 3 (1), 8797 (2008).

34. Fomina, M. \& Gaddm, G. M. Biosorption: current perspectives on concept, definition and application. Bioresour Technol, 160, 3-14 (2014).

35. Forutan, R. et al. Kinetic and equilibrium studies on the adsorption of lead by the chitin of pink shrimp (Solenocera melantho). Entomol Appl Sci Lett, 3, 20-26 (2016).

36. Gao, Y. J. Removal of cadmium and cobalt from heavy metal solution using oyster shells adsorbent. Asian J Chem, 25 (15), 8537-8540 (2013).

37. Green-Ruiz, C., Rodriguez-Tirado, V. \& Gomez-Gil, B. Cadmium and zinc removal from aqueous solutions by Bacillus jeotgali: pH, salinity and temperature effects. Bioresour Technol, 99, 38643870 (2008).

38. Gupta, V., Jaybhaye, S. \& Chandra, N. Biosorption studies of copper, chromium, lead and zinc using fins of Catla catla fish. Int J Res Appl Sci Eng Technol, 5 (4), 902-909 (2017).

39. Gupta, V., Treichel, H., Kuhad, R. \& Rodriguez-Coutom, S. Recent developments in bioenergy research. 1st Edition. Elsevier Science. $472 \mathrm{P}(2020)$.

40. Reddya, H. K., Harinatha, D., Seshaiaha, Y., Reddy, A. V. R. \& K. \& Biosorption of Pb(II) from aqueous solutions using chemically modified Moringa oleifera tree leaves. Chem Eng J, 162, 626-634 (2010).

41. Hayeeye, F., Yu, Q. J., Sattar, M., Chinpa, W. \& Sirichote, O. Adsorption of Pb2+. ions from aqueous solutions by gelatin/activated carbon composite bead form. Adsorp Sci Technol, 36 (1-2), 355-371 (2018).

42. Homagai, P. L., Ghimire, K. N. \& Inoue, K. Adsorption behavior of heavy metals onto chemically modified sugarcane bagasse. Bioresour Technol, 101, 2067-2069 (2010).

43. Hou, W., Zhang, W., Chen, G. \& Luo, Y. Optimization of extraction conditions for maximal phenolic, flavonoid and antioxidant activity from Melaleuca bracteata leaves using the response surface methodology. Plos One, 11 (9), e0162139 (2016). 
44. Iddou, A. Biosorptive removal of lead (II) ions from aqueous solutions using Cystoseira stricta biomass: Study of the surface modification effect.. J Saudi Chem Soc, 15, 83-88 (2011).

45. Ighalo, J. O. \& Eletta, O. A. A. Response surface modelling of the biosorption of $\mathrm{Zn}(\mathrm{II})$ and $\mathrm{Pb}$ (II) onto Micropogonias undulatus scales: Box-Behnken experimental approach. App/ Water Sci. 10(8),197. https://doi.org/10.1007/s13201-020-01283-3(2020).

46. Jimoh, T. O., lyaka, Y. A. \& Nubaye, M. M. Sorption study of $\mathrm{Co}$ (II), $\mathrm{Cu}$ (II) and $\mathrm{Pb}$ (II) ions removal from aqueous solution by adsorption on flamboyant flower (Delonix regia). Am J Chem, 2 (3), 165-170 (2012).

47. Jin, C. S., Deng, R. J., Ren, B. Z., Hou, B. L. \& Hursthouse, A. S. Enhanced biosorption of Sb(III) onto Iving Rhodotorula mucilaginosa strain DJHN070401: Optimization and mechanism. Curr Microbiol, 77, 2071-2083 (2020).

48. Karrari, P., Mehrpour, O. \& Abdollahi, M. A systematic review on status of lead pollution and toxicity in Iran; guidance for preventive measures. Daru, 20 (1), 2 (2012).

49. Kizilkaya, B., Tekinay, A. A. \& Dilgin, Y. Adsorption and removal of $\mathrm{Cu}$ (II) ions from aqueous solution using pretreated fish bones. Desalination, 264 (1-2), 37-47 (2010).

50. Kumar, S. S. \& Bishnoi, N. R. Coagulation of landfill leachate by FeCl3: process optimization using Box-Behnken design (RSM). Appl Water Sci, 7, 1943-1953 (2017).

51. Kwaansa-Ansah, E. E., Nkrumah, D., Nti, S. O. \& Opoku, F. Adsorption of heavy metals (Cu, Mn, Fe and $\mathrm{Ni}$ ) from surface water using Oreochromis niloticus scales. Pollution, 5 (1), 115-122 (2019).

52. Lam, Y. F., Lee, L. Y., Chua, S. J., Lim, S. S. \& Gan, S. Insights into the equilibrium, kinetic and thermodynamics of nickel removal by environmental friendly Lansium domesticum peel adsorbent. Ecotoxicol Environ Saf, 127, 61-70 (2016).

53. Li, X., Liu, Z. \& Chi, Z. Production of phytase by a marine yeast Kodamaea ohmeri BG3 in an oats medium: Optimization by response surface methodology. Bioresour Technol, 99, 6386-6390 (2008).

54. Lodeiro, P., Barriada, J. L., Herrero, R. \& de Sastre, M. E. The marine macroalga Cystoseira baccata as biosorbent for cadmium(II) and lead(II) removal: Kinetic and equilibrium studies. Environ Pollut, 142, 264-273 (2006).

55. Luo, F., Liu, Y., Li, X., Xuan, Z. \& Ma, J. Biosorption of lead ion by chemically-modified biomass of marine brown algae Laminaria japonica. Chemosphere, 64, 1122-1127 (2006).

56. Maghri, I., Kenz, A., Elkouali, M., Tanane, O. \& Talbi, M. Textile dyes removal from industrial waste water by Mytilus edulis shells. J Mater Environ Sci, 3 (1), 121-136 (2012).

57. Mandal, N., Mondal, S., Mondal, A., Mukherjee, K. \& Mondal, B. Response surface modeling of Cu (II) removal from wastewater using fish scale-derived hydroxyapatite: application of Box-Behnken experimental design. Desalin Water Treat, 57 (33), 15410-15423 (2016).

58. Mendoza-Castillo, D. I., Reynel-Avila, H. E., Bonilla-Petriciolet, A. \& Silvestre-Albero, J. Synthesis of denim-waste-based adsorbents and their application in water defluoridation. J Mol Liq, 221, 469478 (2016). 
59. Momčilović, M., Purenović, M., Bojić, A., Zarubica, A. \& Ranđelović, M. Removal of lead (II) ions from aqueous solutions by adsorption onto pine cone activated carbon. Desalination, 276 (1), 53-59 (2011). )

60. Mustakimah, M., Suzana, Y. \& Saikat, M. Decomposition study of calcium carbonate in cockle shell. J Eng Sci Technol, 7 (1), 1-10 (2012).

61. MOOPAM. Manual of oceanographic observations and pollutant analysis methods. Kuwait: Regional Organization for Protection of the Marine Environment (ROPME). 543P (2010).

62. Myers, R. H., Montgomery, D. C. \& Anderson-Cook, C. M. Response surface methodology: Process and product optimization using designed experiments. 4th Edition. John Wiley and Sons, New York. 699 $\mathrm{P}(2016)$.

63. Montgomery, D. C. Design and analysis of experiments. Eighth Edition752 P(John Wiley and Sons, New York, 2012).

64. Mourabet, M., Rhilassi, A. E., Boujaady, H. E., Bennani-Ziatni, M. \& Taitai, A. Use of response surface methodology for optimization of fluoride adsorption in an aqueous solution by Brushite. Arab J Chem, 10, S3292-S3302 https://doi.org/10.1016/j.arabjc.2013.12.028 (2017).

65. Muthulakshmi Andal, N., Charulatha, S., Gayathri, N. S. \& Anuradha, J. A comparative study on the sorption of divalent ions by bivalves shells: Equilibrium and statistical studies. Chem Sci Rev Lett, 5 (19), 214-223 (2016).

66. Nadeem, R. et al. Physical and chemical modification of distillery sludge for Pb(II) biosorption. $J$ Hazard Mater, 150, 335-342 (2008a).

67. Nadeem, R., Ansari, T. M. \& Khalid, A. M. Fourier transform infrared spectroscopic characterization and optimization of $\mathrm{Pb}(\mathrm{II})$ biosorption by fish (Labeo rohita) scales. J Hazard Mater, 156, 64-73 (2008b).

68. Naik, B. R., Suresh, C., Kumar, N. S., Seshaiah, K. \& Reddy, A. V. R. Biosorption of Pb(II) and Ni(II) ions by chemically modified Eclipta alba stem powder: Kinetics and equilibrium studies. Sep Sci Technol, 52 (10), 1717-1732 (2017).

69. Najafi Saleh, H. et al. Data on the acid black 1 dye adsorbtion from aqueous solutions by low-cost adsorbent- Cerastoderma lamarcki shell collected from the northern coast of Caspian Sea. Data Br, 17, 774-780 (2018).

70. Neves, C. V. et al. Phenomenological modeling of reactive dye adsorption onto fish scales surface in the presence of electrolyte and surfactant mixtures. Environ Technol, 39 (19), 2467-2483 (2018).

71. Onwordi, C. T., Uche, C. C., Ameh, A. E. \& Petrik, L. F. Comparative study of the adsorption capacity of lead (II) ions onto bean husk and fish scale from aqueous solution. J Water Reuse Desal, 9 (3), 249262 (2019).

72. Osu, C. I. \& Odoemelam, S. A. Studies on adsorbent dosage, particle sizes and pH constraints on biosorption of $\mathrm{Pb}$ (II) and $\mathrm{Cd}$ (II) lons from aqueous solution using modified and unmodified Crasstrotrea gasar (bivalve) biomass. Inter Arch Appl Sci Technol, 1, 62-68 (2010). 
73. Othman, N., Abd-Kadir, A. \& Zayadi, N. Mozambique tilapia fish scales as potential biosorbent for Zn and $\mathrm{Pb}$ ions removal: kinetic and isotherm studies. 2nd IWA Malaysia Young Water Professional Conference. 17-20 March 2015, Kuala Lumpur, Malaysia. 1-14(2015).

74. Ozseker, K. \& Eruz, C. Pollution assessment of toxic metals in representative limnetic ecosystem sediments in the southeastern Black Sea, Turkey. Clean Soil Air Water, 45 (10), 1700407 (2017).

75. Parida, U., Bastia, T. K. \& Kar, B. B. A Study on the water absorption efficiency of porous silica gel prepared from rice husk ash. Asian J Water Environ Pollut, 14 (1), 83-86 (2017).

76. Park, H. J., Jeong, S. W., Yang, J. K., Kim, B. G. \& Lee, S. M. Removal of heavy metals using waste eggshell. J Environ Sci, 19 (12), 1436-1441 (2007).

77. Park, R., Kim, G., Shen, L., Hong, M. \& Navarro, A. Batch adsorption of heavy metals onto chai tea residues for the bioremediation of contaminated solutions. Curr Top Biotechnol, 8, 51-62 (2014).

78. Pourang, N., Parafkandeh Haghighi, F. \& Moazami, H. R. Hard parts chemical composition as a potentially valuable tool for kutum, Rutilus kutum stock discrimination: A case study of the Southern Caspian Sea. Estuar Coast Shelf Sci, 207, 194-202 (2018).

79. Prabu, K., Shankarlal, S. \& Natarajan, E. A biosorption of heavy metal ions from aqueous solutions using fish scale (Catla catla). World J Fish Mar Sci, 4 (1), 73-77 (2012).

80. Qiu, P. et al. Application of Box-Behnken design with response surface methodology for modeling and optimizing ultrasonic oxidation of arsenite with H2O2. Cent Eur J Chem, 12 (2), 164-172 (2014).

81. Ramrakhiani, L., Ghosh \& Majumdar, S. S. Surface modification of naturally available biomass for enhancement of heavy metal removal efficiency, upscaling prospects, and management aspects of spent biosorbents: A review. Appl Biochem Biotechnol, 180, 41-78 (2016).

82. Regine, H. S., Vieira, F. \& Volesky, B. (2000) A solution to pollution. International Microbiology Biosorption. 3, 17-24 (2016).

83. Risjani, Y., Couteau, J. \& Minier, C. Cellular immune responses and phagocytic activity of fishes exposed to pollution of volcano mud. Mar Environ Res, 96, 73-80 (2014).

84. Rizwan, M., Ali, S., Rehman, M. Z., Javed, M. R. \& Bashir, A. Lead toxicity in cereals and its management strategies: a critical review. Water Air Soil Pollut, 229 (6), 211 (2018).

85. Sahoo, A. K. \& Mishra, P. C. A response surface methodology and desirability approach for predictive modeling and optimization of cutting temperature in machining hardened steel. Int $\mathrm{J}$ Ind Eng Comput, 5 (3), 407-416 (2014).

86. Sari, A. \& Tuzen, M. Biosorption of $\mathrm{Pb}(\mathrm{II})$ and $\mathrm{Cd}(\mathrm{II})$ from aqueous solution using green alga (Ulva lactuca) biomass. J Hazard Mater, 152, 302-308 (2008).

87. Shahzad, S. et al. Removal of heavy metal lead (Pb) (II) by biosorption process using paper shell mussel (Anodontoides ferussacianus). World J Pharm Med Res, 3 (6), 281-288 (2017).

88. Shrestha, B., Kour, J. \& Ghimire, K. N. Adsorptive removal of heavy metals from aqueous solution with environmental friendly material-exhausted tea leaves. Adv Chem Engineer Sci, 6, 525-540 (2016). 
89. Sooksawat, N., Meetam, M., Kruatrachue, M., Pokethitiyook, P. \& Inthorn, D. Performance of packed bed column using Chara aculeolata biomass for removal of $\mathrm{Pb}$ and $\mathrm{Cd}$ ions from wastewater. $J$ Environ Sci Heal A, 52, 539-546 (2017).

90. Sun, X., Chen, J. H., Su, Z., Huang, Y. \& Dong, X. Highly effective removal of Cu(II) by a novel 3aminopropyltriethoxysilane functionalized polyethyleneimine/sodium alginate porous membrane adsorbent. Chem Eng J, 290, 1-11 (2016).

91. Tabari, S., Saeedi Saravi, S. S., Bandany, G. A., Dehghan, A. \& Shokrzadeh, M. Heavy metals (Zn, Pb, $\mathrm{Cd}$ and $\mathrm{Cr}$ ) in fish, water and sediments sampled form Southern Caspian Sea, Iran. Toxicol Ind Health, 26 (10), 649-656 (2010).

92. Tebassi, H. et al. Multi-objective optimization of surface roughness, cutting forces, productivity and power consumption when turning of Inconel 718. Int J Ind Eng Comput, 7, 111-134 (2016).

93. Uddin, M. K. A review on the adsorption of heavy metals by clay minerals, with special focus on the past decade. Chem Eng J, 308, 438-462 (2017).

94. Usman, K., Al-Ghouti, M. A. \& Abu-Dieyeh, M. H. The assessment of cadmium, chromium, copper, and nickel tolerance and bioaccumulation by shrub plant Tetraena qataranse. Sci Rep, 9 (1), 5658 https://doi.org/10.1038/s41598-019-42029-9 (2019).

95. Varshini, J. S. \& Das, N. Enhanced uptake of rare earth metals using surface molecular imprinted biosorbents of animal origin: Equilibrium, kinetic and thermodynamic studies. Int J Chemtech Res, 7 (4), 1913-1919 (2015).

96. Villanueva-Espinosa, J. F., Hernández-Esparza, M. \& Ruiz-Treviño, F. A. Adsorptive properties of fish scales of Oreochromis niloticus (Mojarra Tilapia) for metallic ion removal from waste water. Ind Eng Chem Res, 40 (16), 3563-3569 (2001).

97. Weerasooriyagedra, M. S. \& Anand Kumar, S. Review of utilization of mollusca shell for the removal of contaminants in industrial waste water. Int J Sci Res Publ, 8 (1), 282-287 (2018).

98. Wong, K. H., Li, G. Q., Li, K. M., Razmovski-Naumovski, V., Chan, K. \& \& Optimization of Pueraria isoflavonoids by response surface methodology using ultrasonic-assisted extraction. Food Chem, 231, 231-237 (2017).

99. Xie, R. The importance of surface functional groups in the adsorption of copper onto walnut shell derived activated carbon. Water Sci Technol, 76 (11), 3022-3034 https://doi.org/10.2166/wst (2017).

100. Xu, X., Liu, X., Oh, M. \& Park, J. Oyster shell as a low-cost adsorbent for removing heavy metal ions from wastewater.. Pol J Environ Stud, 28 (4), 2949-2959 (2019). )

101. Yahaya, Y. A. \& Don, M. M. Pycnoporus sanguineus as potential biosorbent for heavy metal removal from aqueous solution: A review. J Phys Sci, 25 (1), 1-32 (2014). )

102. Yan, C., Li, G., Xue, P., Wei, Q. \& \& Li, Q. Competitive effect of Cu(II) and Zn(II) on the biosorption of lead(II) by Myriophyllum spicatum. J Hazard Mater, 179, 721-728 (2010). )

103. Yousefi, Z., Mashayekh-Salehi, A. \& Mohammadpour Tahmtan, R. A. Biosorption of chromium in aqueous solutions using bivalve mollusk shells through central composite design (CCD) model. 
Desalin Water Treat, 57 (42), 19877-19889 (2016).

104. Zabochnicka-Świątek, M. \& Krzywonos, M. Potentials of biosorption and bioaccumulation processes for heavy metal removal. Pol J Environ Stud, 23 (2), 551-561 (2014).

105. Zar, J. H. Biostatistical analysis, 5th Edition, Prentice- Hall. New Jersey: Inc. Englewood Cliffs. 944P(2010).

106. Zayadi, N. \& Othman, N. Characterization and optimization of heavy metals biosorption by fish scales. Adv Mater Res, 795, 260-265 (2013a).

107. Zayadi, N. \& Othman, N. Removal of zinc and ferum lons using Tilapia Mossambica fish scale. Int $J$ Integr Eng, 5 (1), 23-29 (2013b).

108. Zhao, B. et al. Removal of cadmium from aqueous solution using waste shells of golden apple snail. Desalin Water Treat, 57 (50), 23987-24003 (2016).

109. Zhu, Q. \& Li, Z. Hydrogel-supported nanosized hydrous manganese dioxide: synthesis, characterization, and adsorption behavior study for $\mathrm{Pb} 2+, \mathrm{Cu} 2+, \mathrm{Cd} 2+$ and $\mathrm{Ni} 2+$ removal from water. Chem Eng, 281, 69-80 https://doi.org/10.1016/j.cej.2015.06.068 (2015).

110. Zhu, C., Dong, X., Chen, Z. \& Naidu, R. Adsorption of aqueous $\mathrm{Pb}(\mathrm{II}), \mathrm{Cu}(\mathrm{II}), \mathrm{Zn}(\mathrm{II})$ ions by amorphous tin(VI) hydrogen phosphate: an excellent inorganic adsorbent. Int J Environ Sci Technol, 13, 12571268 (2016).

\section{Figures}




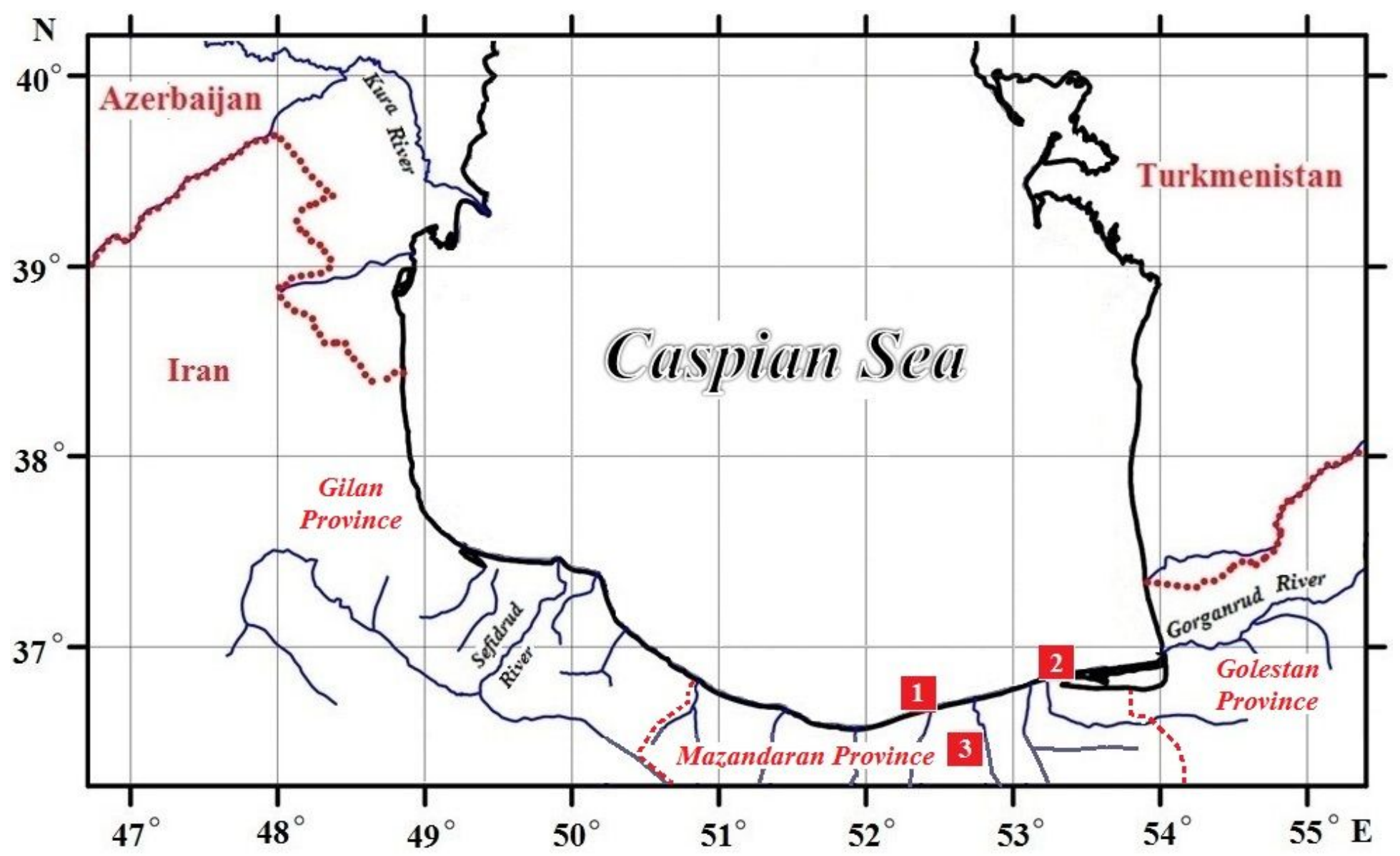

Figure 1

Map of the Caspian Sea showing the locations of collection of the specimens. 1: Rutilus kutum, 2: Cerastoderma glaucum, 3: Oncorhynchus mykiss.

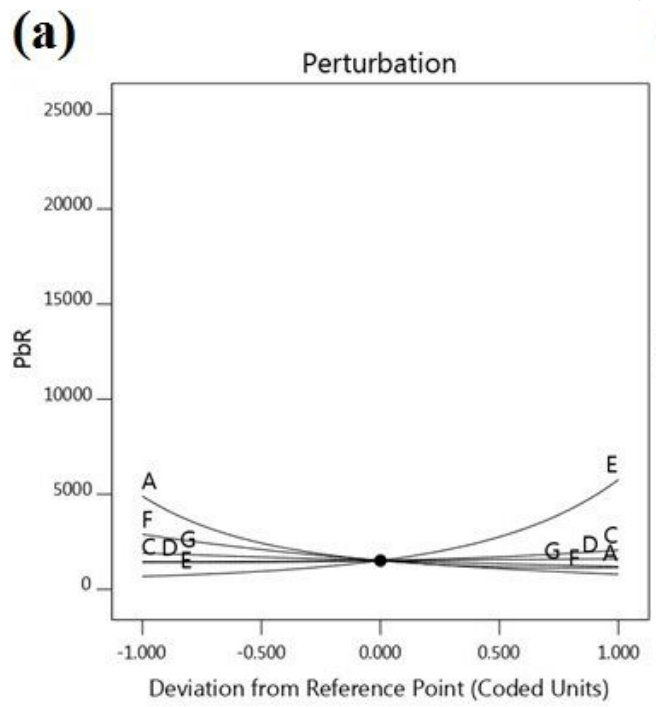

(b)

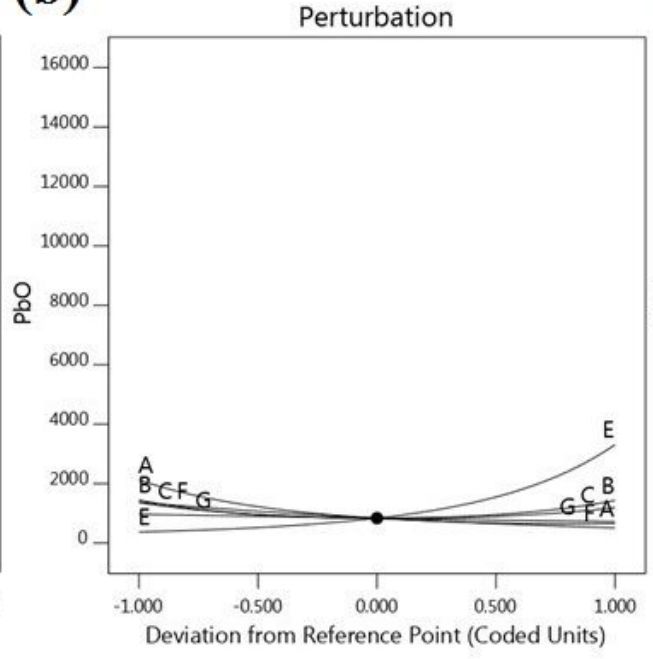

(c)

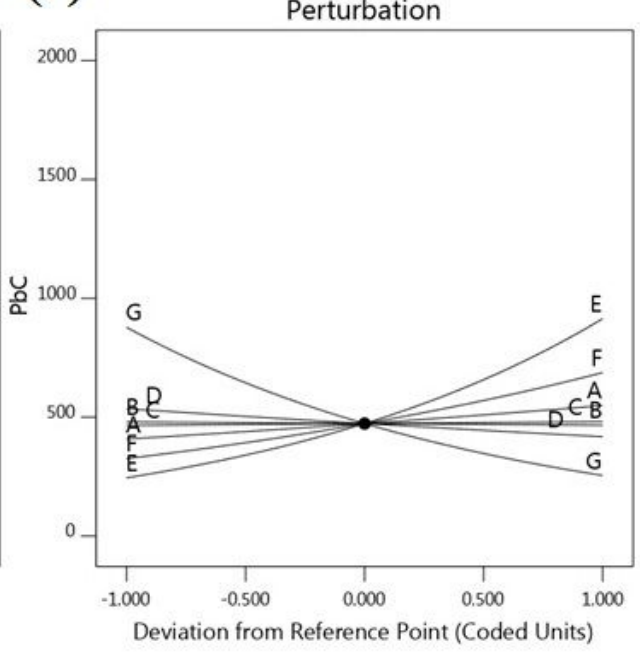

Figure 2

Perturbation plots showing the effect of all factors. (A: biosorbent dosage, B: biosorbent size, C: contact time, D: temperature, E: initial concentration, $\mathrm{F}: \mathrm{pH}$ and G: salinity) on the response variables (a: $\mathrm{PbR}, \mathrm{b}$ : 
$\mathrm{PbO}, \mathrm{c}: \mathrm{PbC})$.

(a)
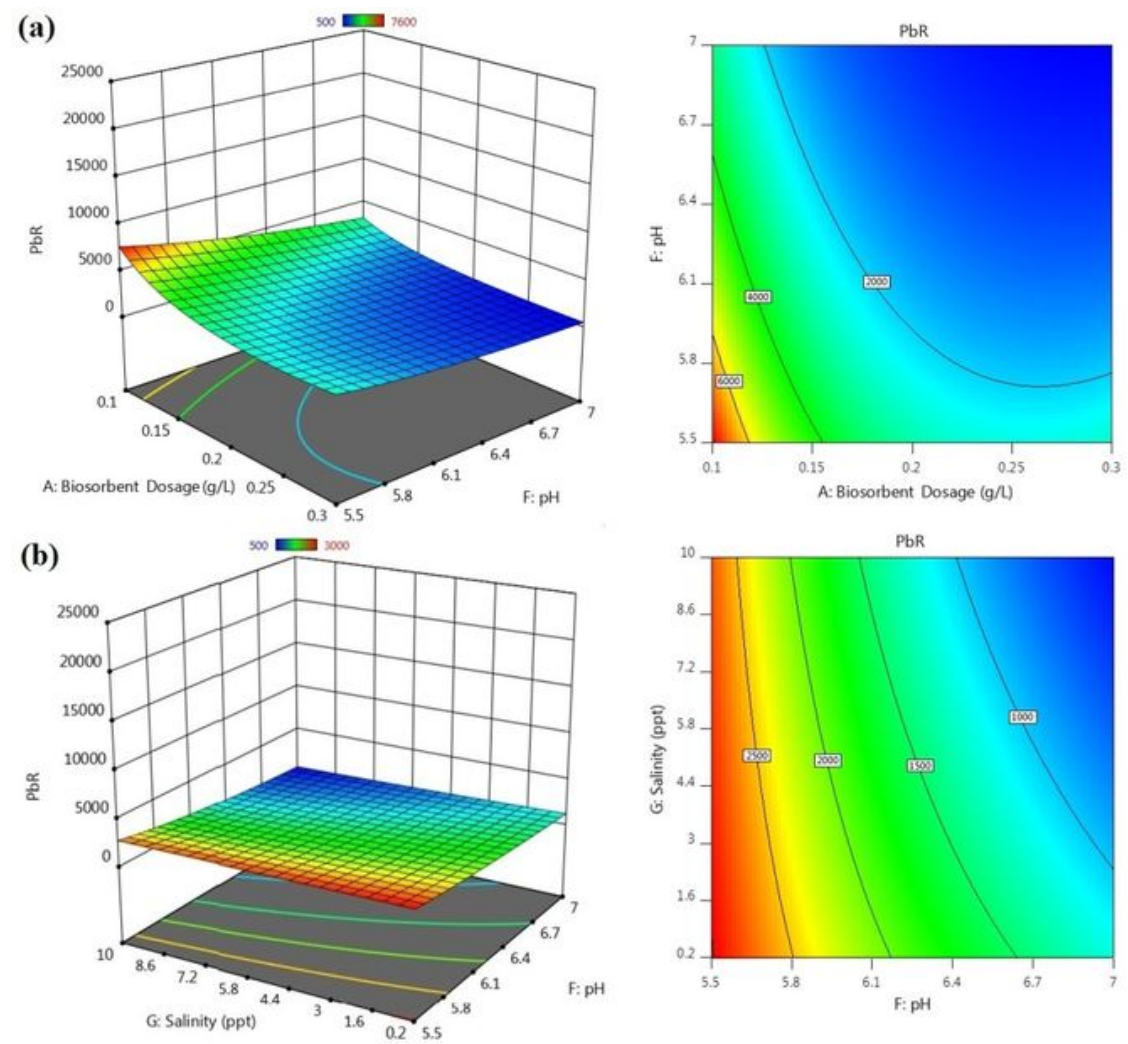

(c)
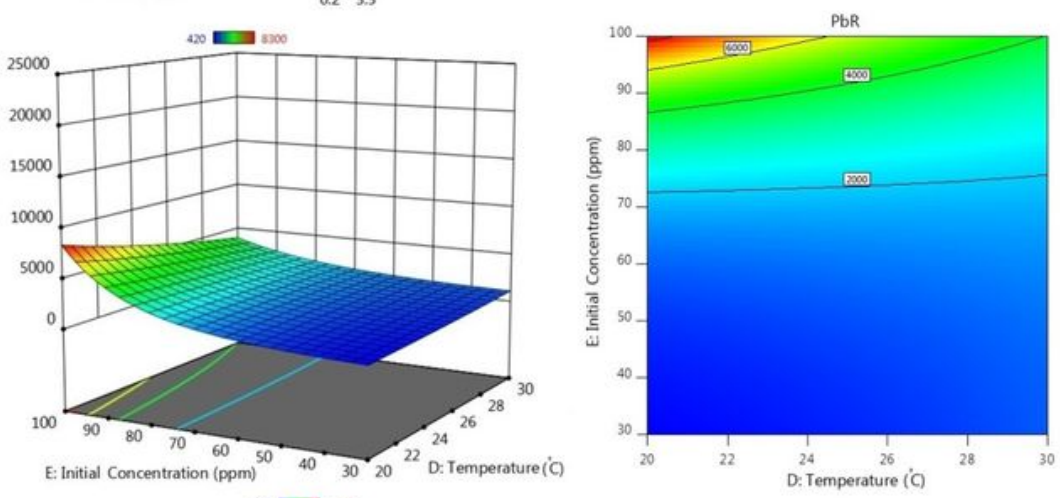

(d)
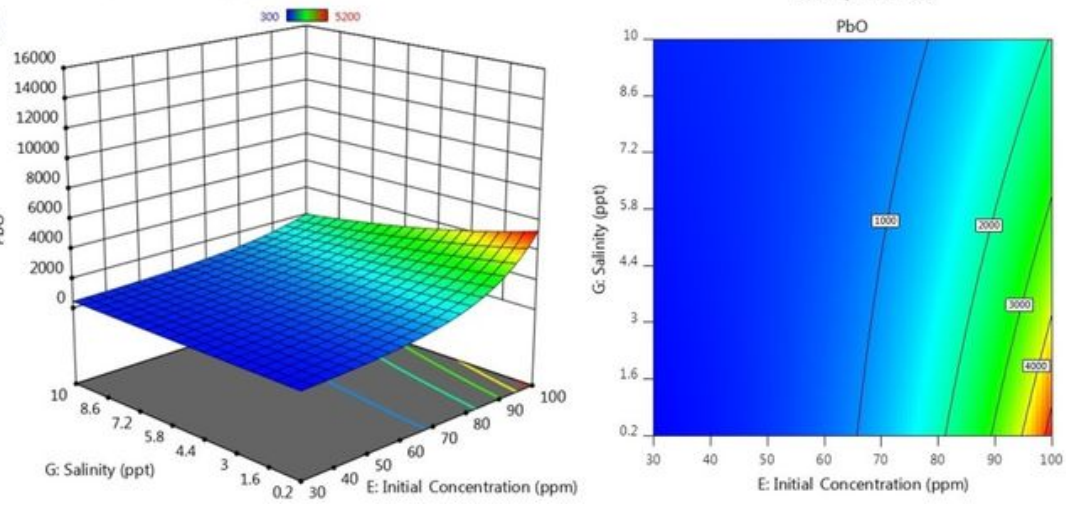

\section{Figure 3}

$3 \mathrm{D}$ response surface plots and contour curves showing the interactive effects of (a) $\mathrm{pH}$ and biosorbent dosage on $\mathrm{PbR}$, (b) $\mathrm{pH}$ and salinity on $\mathrm{PbR}$, (c) temperature and initial concentration on $\mathrm{PbR}$, (d) initial concentration and salinity on $\mathrm{PbO}$. 
(a)

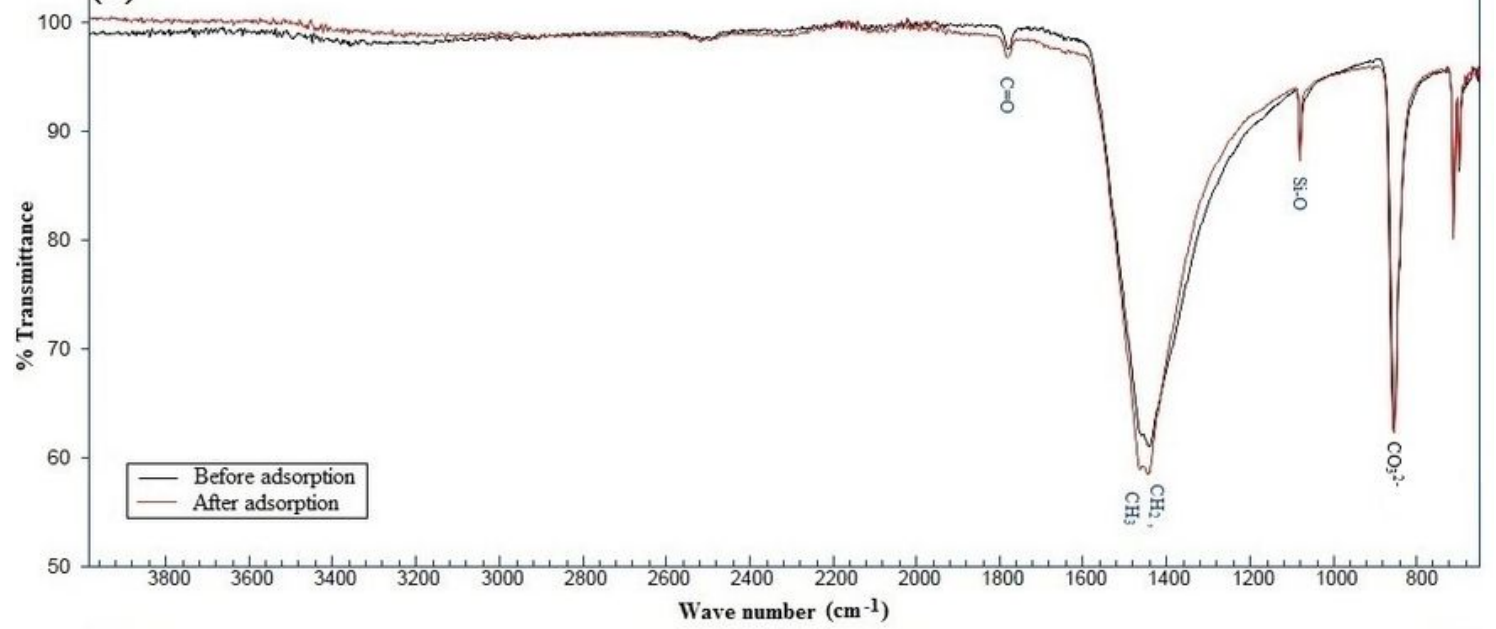

(b)
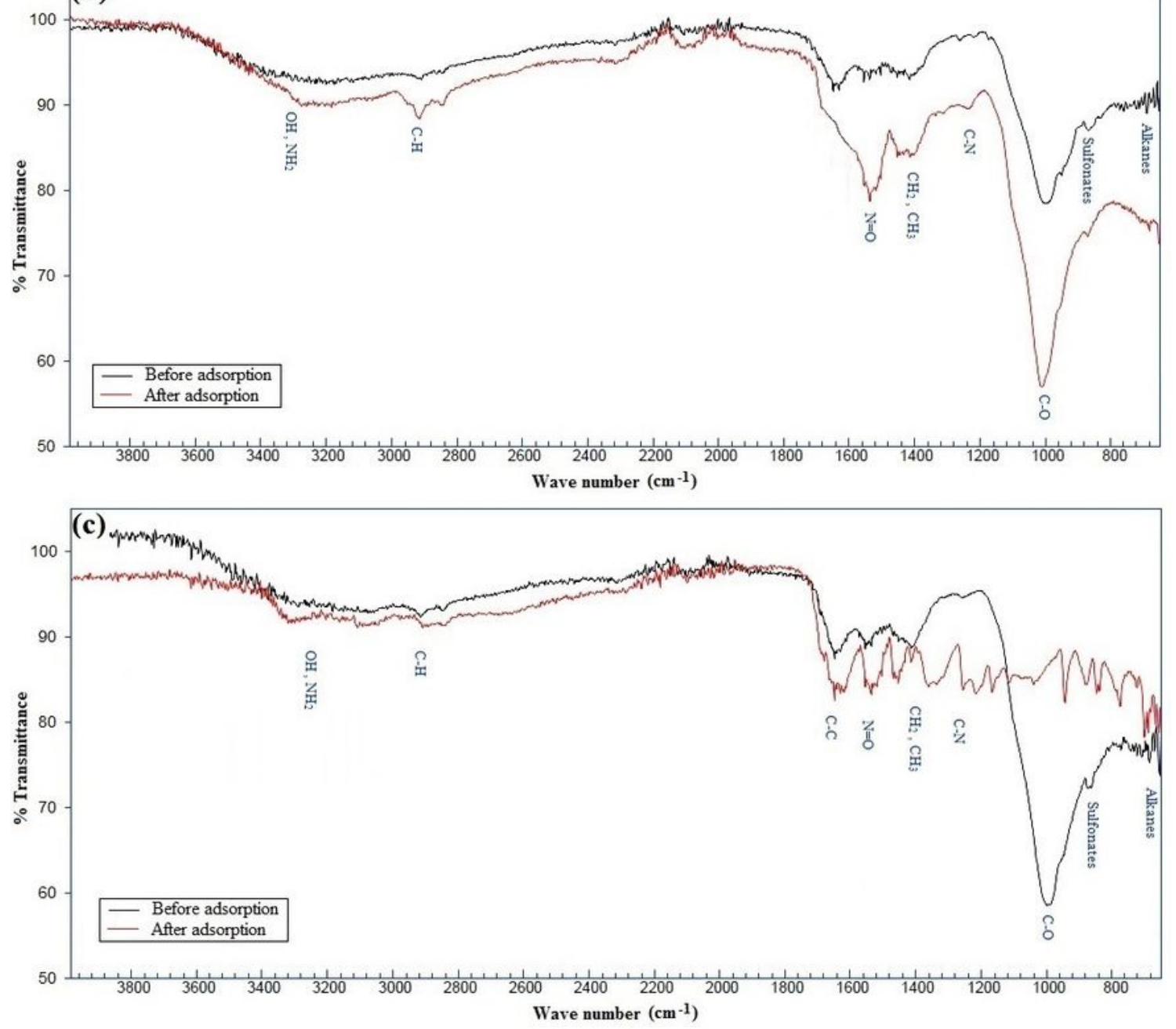

\section{Figure 4}

FTIR spectra of C. glaucum shell (a), O. mykiss scale (b), and R. kutum scale (c) before and after Pb adsorption indicating corresponding functional groups. 
(a)

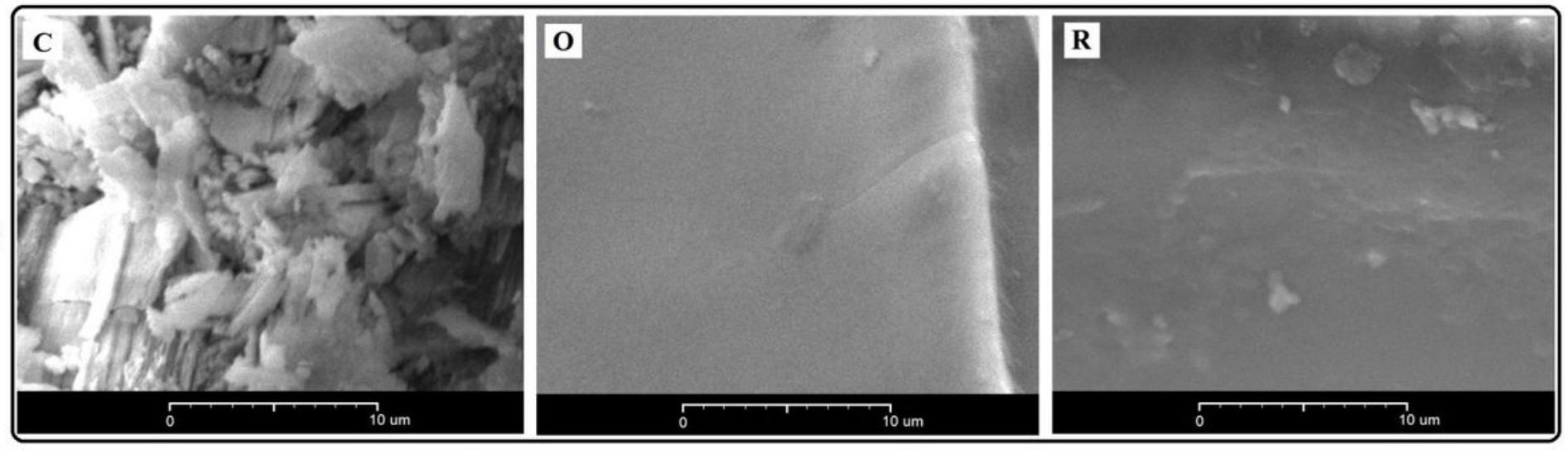

(b)

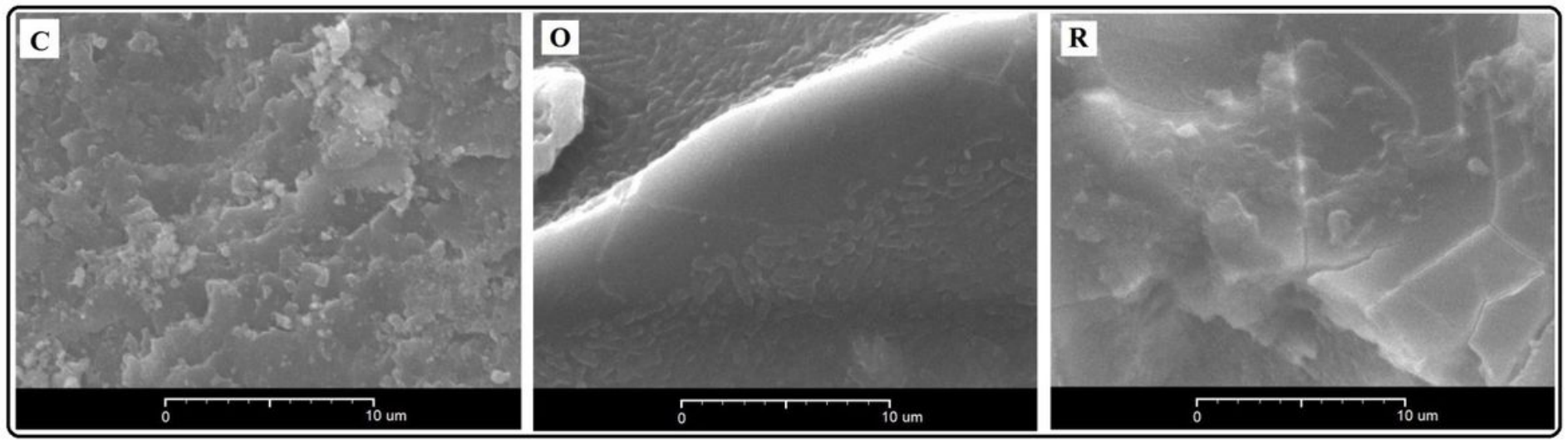

Figure 5

SEM micrographs at 3000× magnification before (a) and after (b) Pb biosorption for C. glaucum shell (C), O. mykiss scale (O), and R. kutum scale (R). 

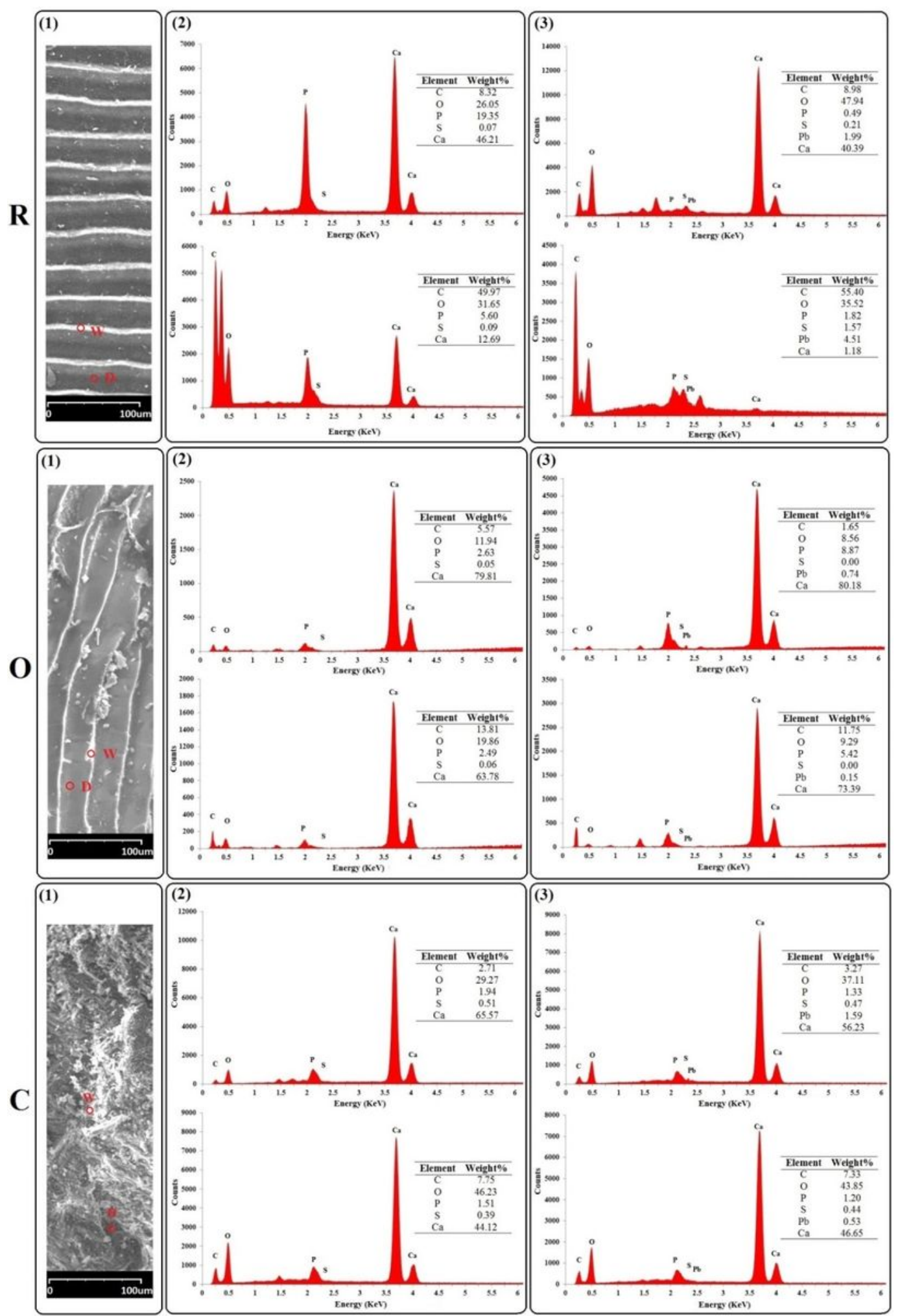

Figure 6

SEM images and corresponding EDX spectra of the three selected biosorbents (R: R. kutum scales; O: O. mykiss scales; C: C. glaucum shells): 1$)$ the selected white (W) and dark (D) spots on the samples $(\times 200$ magnification), 2) EDX spectra of the white (upper) and dark (lower) spots before Cu biosorption, 3) EDX spectra of the white (upper) and dark (lower) spots after $\mathrm{Pb}$ biosorption. Insets: Elemental composition (weight percentage). 

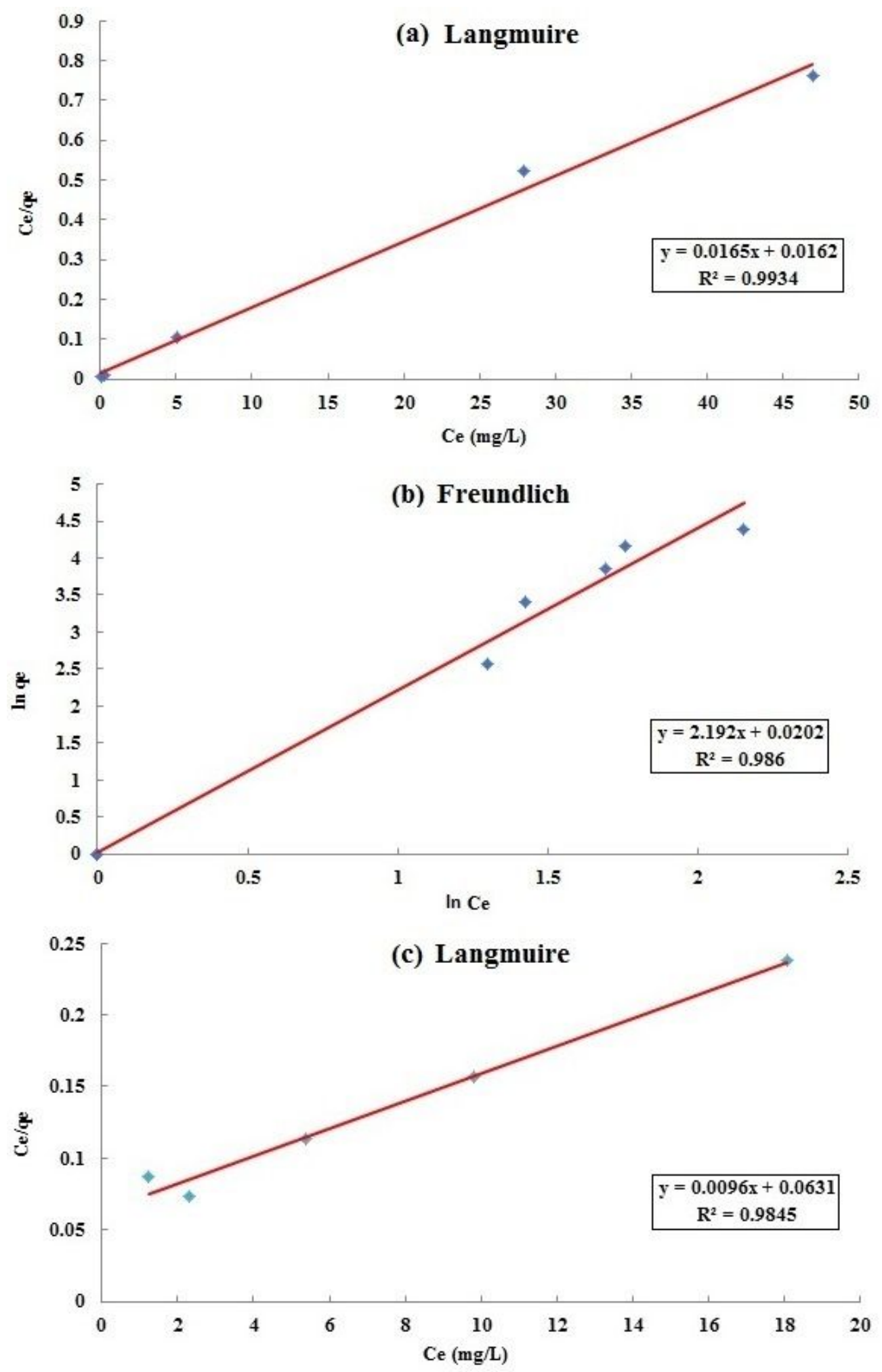

\section{Figure 7}

(a) Langmuir, (b) Freundlich and (c) Langmuir isotherm plots for lead adsorption onto R. kutum scale, 0. mykiss scale and C. glaucum shell, respectively. 